\title{
Review \\ Review on Methylene Blue: Its Properties, Uses, Toxicity and Photodegradation
}

\author{
Idrees Khan ${ }^{1,2, *}$, Khalid Saeed ${ }^{2}$, Ivar Zekker ${ }^{3, *}$, Baoliang Zhang ${ }^{1}$, Abdulmajeed H. Hendi $\left.{ }^{4}{ }^{(}\right)$, Ashfaq Ahmad ${ }^{5}{ }^{(0)}$, \\ Shujaat Ahmad ${ }^{6}{ }^{(}$, Noor Zada ${ }^{7}$, Hanif Ahmad ${ }^{7}$, Luqman Ali Shah ${ }^{8}{ }^{(D}$, Tariq Shah ${ }^{1}$ and Ibrahim Khan ${ }^{9}(\mathbb{D}$
}

Citation: Khan, I.; Saeed, K.; Zekker, I.; Zhang, B.; Hendi, A.H.; Ahmad,

A.; Ahmad, S.; Zada, N.; Ahmad, H.; Shah, L.A.; et al. Review on Methylene Blue: Its Properties, Uses, Toxicity and Photodegradation. Water 2022, 14, 242. https://doi.org/ $10.3390 / \mathrm{w} 14020242$

Academic Editor: John Zhou

Received: 30 November 2021

Accepted: 12 January 2022

Published: 14 January 2022

Publisher's Note: MDPI stays neutral with regard to jurisdictional claims in published maps and institutional affiliations.

Copyright: (C) 2022 by the authors. Licensee MDPI, Basel, Switzerland. This article is an open access article distributed under the terms and conditions of the Creative Commons Attribution (CC BY) license (https:// creativecommons.org/licenses/by/ $4.0 /)$.
1 School of Chemistry and Chemical Engineering, Northwestern Polytechnical University, Xi'an 710129, China; blzhang@nwpu.edu.cn (B.Z.); tariqshah00077@gmail.com (T.S.)

2 Department of Chemistry, Bacha Khan University, Charsadda 24420, Pakistan; khalidkhalil2002@yahoo.com

3 Institute of Chemistry, University of Tartu, 14a Ravila St., 50411 Tartu, Estonia

4 Physics Department \& IRC-Hydrogen and Energy Storage, King Fahd University of Petroleum and Minerals, Dhahran 31261, Saudi Arabia; ahendi@kfupm.edu.sa

5 Department of Chemistry, College of Science, King Saud University, Riyadh 11451, Saudi Arabia; aahmad1@ksu.edu.sa

6 Department of Pharmacy, Shaheed Benazir Bhutto University, Sheringal 18050, Pakistan; shujaat@sbbu.edu.pk

7 Department of Chemistry, University of Malakand, Chakdara 18800, Pakistan; syednoorzada88@gmail.com (N.Z.); akhund83@gmail.com (H.A.)

8 National Center of Excellence in Physical Chemistry (NCE), University of Peshawar, Peshawar 25120, Pakistan; luqman_alisha@uop.edu.pk

9 School of Chemical Engineering \& Materials Science, Chung-Ang University, 84 Heukseok-ro, Dongjak-gu, Seoul 06974, Korea; ebraheemchem@cau.ac.kr

* Correspondence: idreeschem_uom@yahoo.com (I.K.); ivar.zekker@ut.ee (I.Z.)

\begin{abstract}
The unavailability of clean drinking water is one of the significant health issues in modern times. Industrial dyes are one of the dominant chemicals that make water unfit for drinking. Among these dyes, methylene blue (MB) is toxic, carcinogenic, and non-biodegradable and can cause a severe threat to human health and environmental safety. It is usually released in natural water sources, which becomes a health threat to human beings and living organisms. Hence, there is a need to develop an environmentally friendly, efficient technology for removing MB from wastewater. Photodegradation is an advanced oxidation process widely used for MB removal. It has the advantages of complete mineralization of dye into simple and nontoxic species with the potential to decrease the processing cost. This review provides a tutorial basis for the readers working in the dye degradation research area. We not only covered the basic principles of the process but also provided a wide range of previously published work on advanced photocatalytic systems (single-component and multi-component photocatalysts). Our study has focused on critical parameters that can affect the photodegradation rate of $\mathrm{MB}$, such as photocatalyst type and loading, irradiation reaction time, $\mathrm{pH}$ of reaction media, initial concentration of dye, radical scavengers and oxidising agents. The photodegradation mechanism, reaction pathways, intermediate products, and final products of $\mathrm{MB}$ are also summarized. An overview of the future perspectives to utilize $\mathrm{MB}$ at an industrial scale is also provided. This paper identifies strategies for the development of effective MB photodegradation systems.
\end{abstract}

Keywords: methylene blue (MB); photodegradation; toxicity; degradation parameter; mechanism; degradation products

\section{Introduction}

Dyes are the coloured aromatic organic compounds that absorb light and impart color to the visible region [1,2]. More than 100,000 commercial dyes have been reported worldwide, amounting to approximately $7 \times 10^{8}-1 \times 10^{9} \mathrm{~kg} /$ year [3]. William Henry Perkin discovered the first synthetic dye in 1856, naming it Mauveine (an organic aniline dye) [4]. Dyes are applied to the substrates to give them permanent colour, which can resist 
fading upon exposure to water, light, oxidizing agents, sweat, and microbial attack [5]. Due to these advantages, various dyes are used in different industries such as textiles, food, rubber, printing, cosmetics, medicine, plastic, concrete, and the paper industry for multiple purposes [6-8]. These industries generate a tremendous amount of wastewater containing carcinogenic and toxic dyes that pollute water, which becomes unfit for human consumption [9]. Among these industries, the textile industry is the most dye-consuming industry utilizing textile dyes, which are highly complex compounds with different structural groups [10]. One of the highest-consuming materials in the dye industry is methylene blue (MB), which is commonly used for colouring silk, wool, cotton, and paper [11-13]. The Scopus database indicates that MB is widely utilized for various applications. The number of articles on MB dye degradation has been continuously increasing since 2010-2020, as shown in Figure 1.

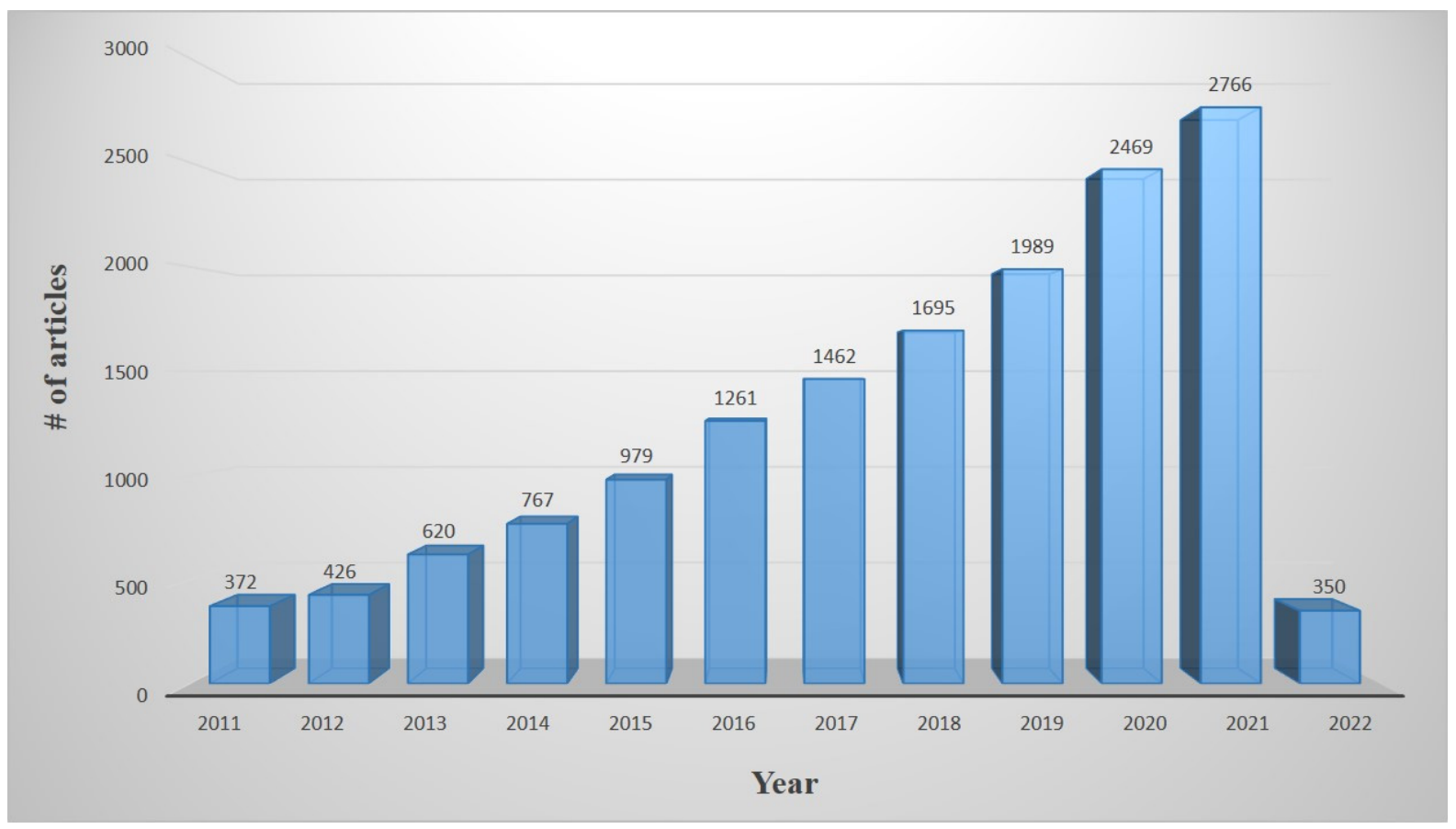

Figure 1. Annual article frequency as indicated by the Scopus database at date 12 January 2022 (Searched with a keyword 'methylene blue dye degradation').

Certain literature reviews are reported on the removal of MB via adsorption [14-16] and bioremediation [17]. However, minimal reviews are available on photodegradation of $\mathrm{MB}$, which only describes fundamentals and photocatalysis of MB dye employing various nanocatalytic assemblies [18]. In this review, we discuss the properties, applications, toxicity, and available use methods for the removal of $\mathrm{MB}$, with limitations. Moreover, photodegradation of MB and its advantages, factors affecting parameters, and photodegradation and intermediate products will be reviewed in detail.

$\mathrm{MB}$ is an aromatic heterocyclic basic dye [19] having a molecular weight of $319.85 \mathrm{~g} \mathrm{~mol}^{-1}$ $[20,21]$. MB is a well-known cationic and primary thiazine dye with a molecular formula$\mathrm{C}_{16} \mathrm{H}_{18} \mathrm{~N}_{3} \mathrm{ClS}$, having $\lambda_{\max }$ of $663 \mathrm{~nm}$. It is highly water-soluble, and thus forms a stable solution with water at room temperature [22-25]. MB comes under the class of polymethine dye with an amino autochrome unit and is a positively charged compound [26]. Its chemical name, according to the International Union of Pure and Applied Chemistry (IUPAC), is [3,7-bis(dimethylamino) phenothiazine chloride tetra methylthionine chloride] with colour index (CI) 52015 [27,28]. The model and the structure of the MB molecule are shown in Figure 2 [29], while its different resonance structures are given in Figure 3 [30]. MB is a redox indicator and not a $\mathrm{pH}$ indicator [31]. $\mathrm{MB}$ was first synthesized by Heinrich Caro in 1800 [32]. 


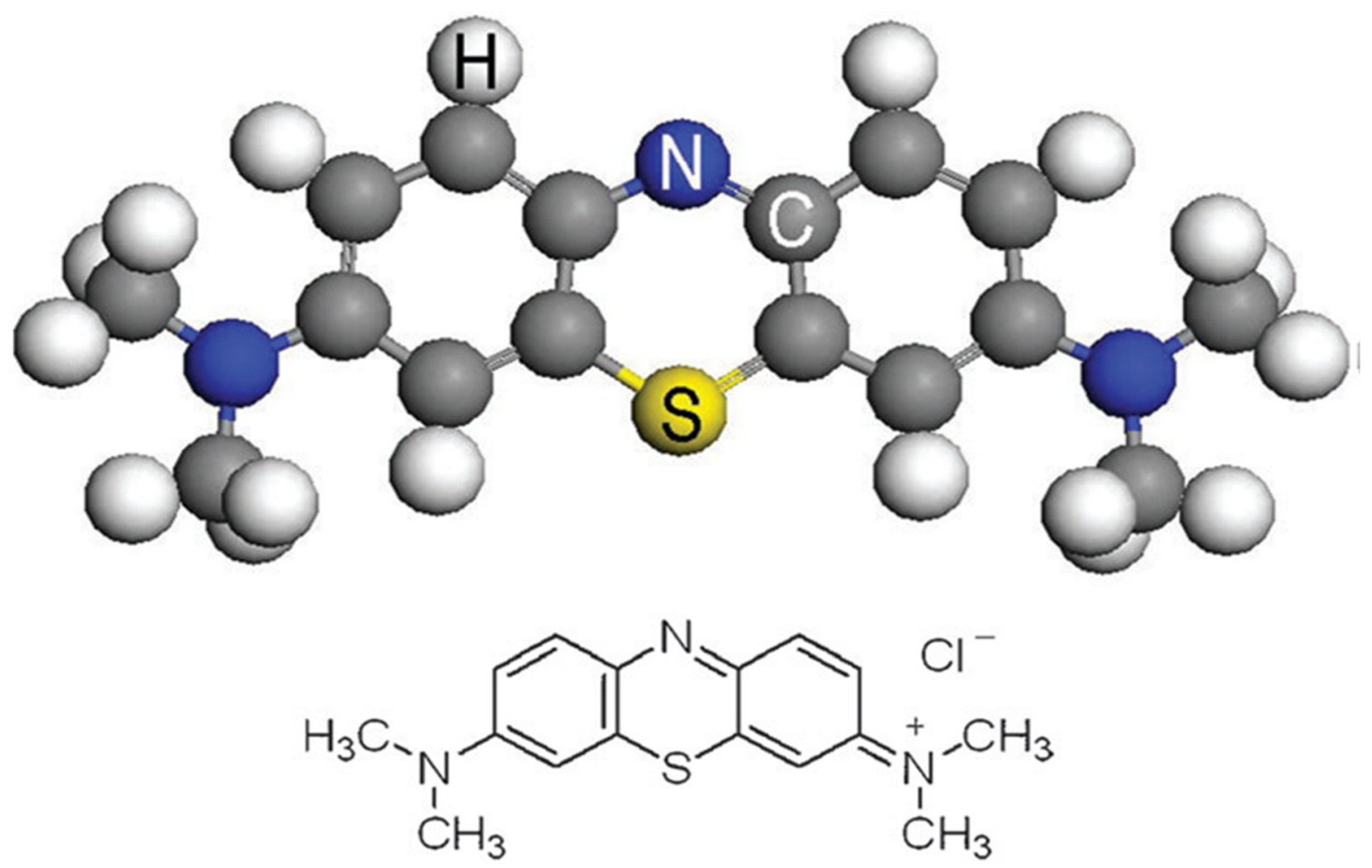

Figure 2. The model and the structure of MB dye molecule [29] (Adapted with permission from the Royal. Society of Chemistry (license ID 1079849-1).<smiles>CN(C)c1ccc2c(c1)[S+](Cl)=c1cc(N(C)C)ccc1=N2</smiles><smiles>CN(C)c1ccc2nc3ccc(=[N+](C)C)cc-3sc2c1</smiles>

Figure 3. Different resonance structures of MB.

Photodegradation is an advanced and economical technology which utilises solar energy and employs a catalyst (mostly photoactive materials of nano-level size). Various nanomaterials have been reported for this purpose, including $\mathrm{ZnS}[33], \mathrm{TiO}_{2}[34,35]$, 
$\mathrm{ZnO}$ [36], hematite [37-39], plasmonic metals (such as gold, silver, platinum) [40,41], $\mathrm{Ag}_{2} \mathrm{~S} \mathrm{TiO}_{2}$ nanofibers [42] metal vanadates (those of $\mathrm{Bi}, \mathrm{Ni}, \mathrm{Cu}, \mathrm{Zn}$ etc.) [43-47], carbonbased catalysts such as graphene and its oxides, and carbon nitrides, [48-51], magnetite nanoparticles (NPs) and iron (III) oxide-based catalysts [52,53]. These systems have demonstrated exceptional results. It is expected that understanding the basics of degradation of $M B$ via this technology will shift the researchers' attention to a more advanced level of such a technology. Limited reviews are reported on removing MB dye via adsorption [14,15]. Still, there is no specific review on photodegradation of MB by single-component and multicomponent photocatalytic systems so far, to the best of the authors' knowledge. This review collectively highlights the single component and multi-component photocatalytic systems as effective and promising technologies for removing $\mathrm{MB}$ from industrial wastewater. The influence of operating parameters on the degradation of $\mathrm{MB}$ by various photocatalytic systems is also examined. This review is focused to provide guidelines for developing effective photocatalytic systems for MB degradation from wastewater.

\section{Properties of Methylene Blue}

$\mathrm{MB}$ is a solid, odourless, dark green powder at room temperature and yields a blue solution when dissolved in water [54,55]. MB have molecular diffusivity (Dmol) of $4.7 \times 106\left(\mathrm{~cm}^{2} / \mathrm{s}\right)$ at $25^{\circ} \mathrm{C}[56]$. The length of MB molecule is $13.82 \AA$ or $14.47 \AA$, and the width is approximately $9.5 \AA$ [57]. MB dye has a $\mathrm{pK}_{\mathrm{a}}$ of 3.8 [58,59]. It is soluble in methanol, 2-propanol, water, ethanol, acetone, and ethyl acetate [60]. Its solubility in water is $43.6 \mathrm{~g} / \mathrm{L}$ at $25{ }^{\circ} \mathrm{C}$ [61]. The melting point $(\mathrm{Tm})$ of $\mathrm{MB}$ is in the range $100-110^{\circ} \mathrm{C}$ [62].

$\mathrm{MB}$ has a characteristic deep blue colour in the oxidized state and is colourless in the reduced form; leucoMB [63]. The structure of both forms is represented in Figure 4 [64,65]. The colour of MB depends on its chromophoric and auxochrome groups. The chromophore group of $\mathrm{MB}$ is the $\mathrm{N}-\mathrm{S}$ conjugated system on the central aromatic heterocycle, while the auxochrome group is $\mathrm{N}$-containing groups with lone pair electrons on the benzene ring [66]. In photodegradation and adsorption studies, UV-analysis of MB is very important, as almost all calculations are measured from its UV-Visible spectra. The absorption spectra of the $\mathrm{MB}$ reveal the most intense absorption peak at around $664 \mathrm{~nm}$ associated with an $\mathrm{MB}$ monomer, with a shoulder peak at about $612 \mathrm{~nm}$ attributed to MB dimer. An additional two bands appear in the ultraviolet region with peaks around 292 and $245 \mathrm{~nm}$ (associated with substituted benzene rings) [67]. These absorption peaks gradually decrease as the photodegradation reaction proceeds [68]. Fourier transform infrared-spectroscopy (FTIR) also provides important quantitative and qualitative analysis for the studied dyes. This includes identifying the chemical bonds and functional groups in the study sample. Various FTIR peaks of MB and their assignments are summarized in Table 1.

Table 1. FTIR spectra and assignment of MB [69-71].

\begin{tabular}{ll}
\hline FTIR Transmission Wavenumbers $\left.\mathbf{( c m}^{-\mathbf{1}}\right)$ & Assignments \\
\hline 3410 & -NH/-OH overlapped stretching vibration \\
2928 & symmetrical stretching $\mathrm{C}-\mathrm{H}$ of $-\mathrm{CH}_{2}$ band \\
1600 & $\mathrm{C}=\mathrm{N}$ central ring stretching \\
1482 & $\mathrm{C}=\mathrm{C}$ side ring stretching \\
1384 & multiple ring stretching \\
1590 & skeleton stretching vibration of the benzene ring \\
1486.4 and 1389 & stretching vibration of $\mathrm{C}-\mathrm{N}$ in aromatic amines \\
1320 & $\mathrm{C}_{\text {Ar }}-\mathrm{N}$ stretching \\
1572 & stretching band of $\mathrm{C}=\mathrm{O}, \mathrm{C}-\mathrm{N}$ of amide II \\
1240 and 1182 & $\mathrm{~N}-\mathrm{CH}_{3}$ stretching \\
1143 & stretching vibration of $\mathrm{C}-\mathrm{N}$ in the aliphatic chain \\
1442 & symmetrical stretching band of $-\mathrm{COOH}$ \\
1140 and 854 & bending band of $\mathrm{N}-\mathrm{H}$ and $\mathrm{C}-\mathrm{N}$ from the amide III \\
880 & absorption of $\mathrm{C}-\mathrm{H}$ in-plane bending vibration \\
665 & skeleton vibration mode of $\mathrm{C}-\mathrm{S}-\mathrm{C}$ \\
\hline
\end{tabular}


Reduced form (Colorless)

Oxidized form (Blue)

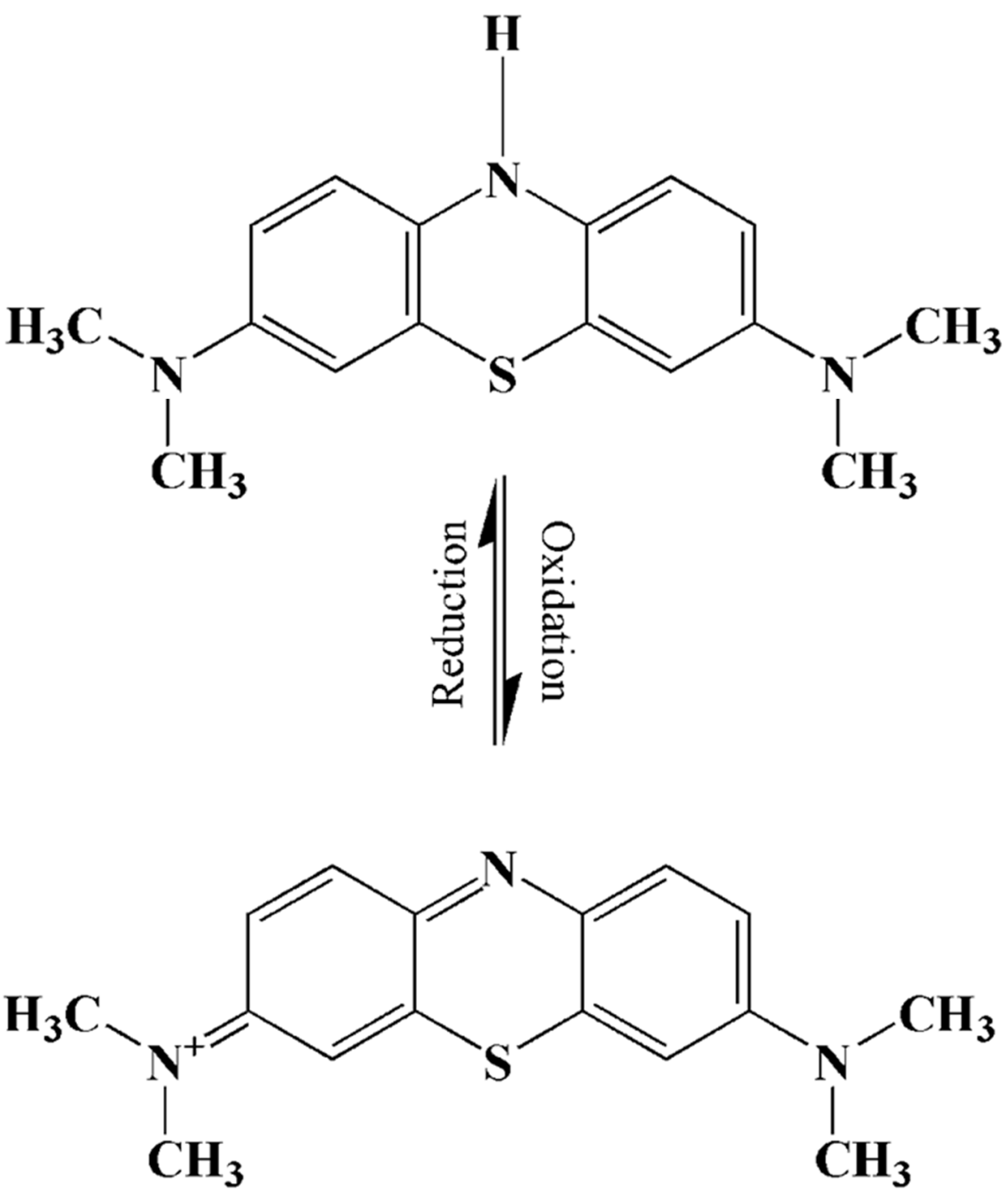

Figure 4. Oxidized and reduced forms of MB.

\section{Uses and Applications of Methylene Blue}

$\mathrm{MB}$ is an attractive molecule with various properties useful for biomedical applications and is used as an effective therapeutic agent to treat anaemia, malaria, and Barrett's oesophagus [72]. MB has primarily been used in human and veterinary medicine for several diagnostic and therapeutic procedures [73].

MB was the first synthetic antimalarial used during the late 19th and the early 20th centuries against all types of malaria and can also act as a chloroquine sensitizer [74,75]. MB dye is being used for the photodynamic treatment of cancer [76]. It is widely used as a photosensitizing agent for photodynamic inactivation of RNA viruses (including HIV, hepatitis B, and hepatitis $C$ viruses) in plasma [77]. Recent studies have suggested that MB has beneficial effects on memory improvement and Alzheimer's disease. Presently, it is used clinically in a wide range of medications that treat conditions such as such as methemoglobinemia, urinary tract infections, plaque psoriasis, thyroid surgery, cancer chemotherapy, and ifosfamide-induced encephalopathy [78,79]. MB served as the leading compound for developing tricyclic antidepressants- chlorpromazine [80]. It has also been used to detect neuroendocrine tumours, such as insulinoma [81].

MB dye has many potential applications in the textile, pharmaceutical, paper, dyeing, printing, paint, medicine, and food industries [82-85]. It is the most common dye in the textile industry [86], and is considered one of the most popular clothing colourants [87]. MB firmly adheres in the interstitial spaces of cotton fibres and is fixed firmly on fabric in the 
textile industry [88]. MB is used to estimate rock swelling, which is used as a quick test to assess the quality of foundry sand in foundries [89]. MB dye is also used as a photosensitizer, an oxidation-reduction indicator, an optical redox indicator in analytical chemistry and in the trace analysis of anionic surfactants [90-92]. It is also used as a potential material in dye-sensitized solar cells [93,94], capacitors [95], sensors [96,97], microbial fuel cells [98], etc.

\section{Toxicity of Methylene Blue}

Textile industries usually release a large amount of MB dyes in natural water sources, which becomes a health threat to human beings and microbes [99]. MB dye is harmful to human health above a certain concentration due to its substantial toxicity [24]. MB is toxic, carcinogenic, and non-biodegradable and can cause a serious threat to human health and destructive effects on the environment $[100,101]$. MB causes several risks to human health such as respiratory distress, abdominal disorders, blindness, and digestive and mental disorders $[15,102]$. It also causes nausea, diarrhoea, vomiting, cyanosis, shock, gastritis, jaundice, methemoglobinemia, tissue necrosis, and increased heart rate, causing the death of premature cells in tissues and skin/eye irritations [103-107]. MB contacts with skin may result in skin redness and itching [108]. The no observed adverse effect level (NOAEL) for the MB in rats was observed to be $25 \mathrm{mg} \mathrm{kg}^{-1}$ [109]. Some of the toxic effects of MB on humans and other animals are represented in Figure 5 [110]. MB discharge into the environment is a significant threat for aesthetical and toxicological reasons. It also reduces light penetration and is a toxic supply to food chains for organisms [111]. MB presence in water bodies, even at a very low concentration, makes highly coloured sub-products. Owing to its high molar absorption coefficient $\left(\sim 8.4 \times 10^{4} \mathrm{~L} \mathrm{~mol}^{-1} \mathrm{~cm}^{-1}\right.$ at $664 \mathrm{~nm}$ ), which reduces sunlight transmittance, it decreases oxygen solubility, affects the photosynthetic activity of aquatic life, and decreases the diversity and aesthetics of the biological community [112-115].

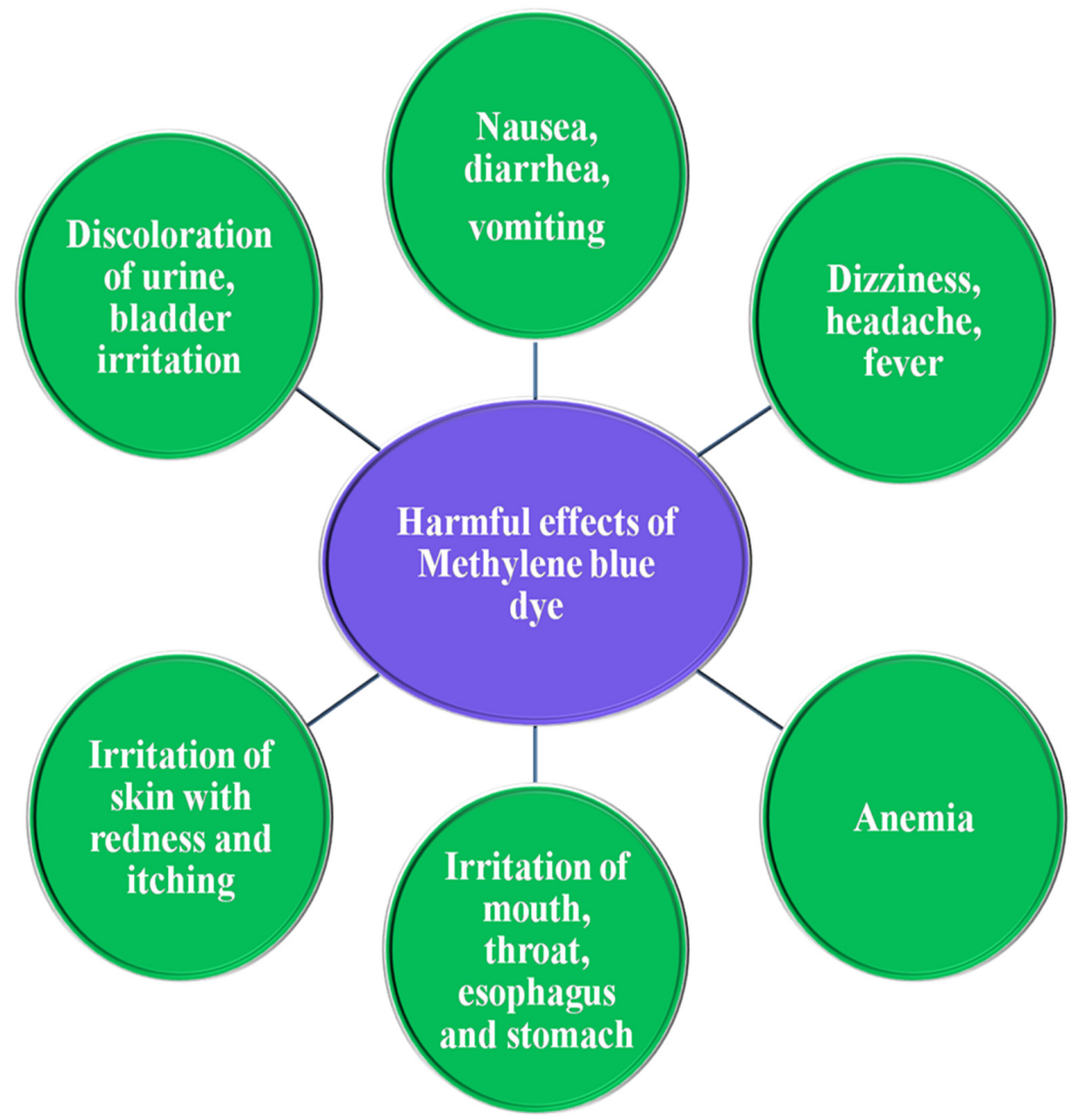

Figure 5. Harmful effects of the MB dye. 


\section{Methods of Removal of Methylene Blue}

Treatment of wastewater containing MB dye before discharging into the environment is of great importance due to its harmful impacts on water quality and perception $[116,117]$. Various methods are reported to remove $\mathrm{MB}$ and other textile dyes from industrial wastewater. These include adsorption/biosorption [118-123], phytoremediation [124,125], coagulation [126,127] electrocoagulation [56,128], vacuum membrane distillation [129], liquidliquid extraction [130], ultrafiltration [131-133], nanofiltration [134-136], microwave treatment [137], biodegradation [138-140], hybrid systems [141-144] etc. Due to the thermal and light stability and non-biodegradability, it is tough to degrade MB dye into smaller inorganic molecules by employing common methods $[145,146]$. Each of these treatment methods has its advantages and constraints in terms of cost and feasibility, efficiency, and environmental impact [147]. Advanced oxidation processes (AOPs) were developed to treat toxic organic pollutants such as $\mathrm{MB}$ through strong redox processes with specific radicals generated in this process without generating any additional harmful substances [148-150]. AOPs approaches employed for the photodegradation of $\mathrm{MB}$ are ozonation [151,152], $\mathrm{UV} / \mathrm{H}_{2} \mathrm{O}_{2}$ oxidation [153] electrochemical oxidation/degradation [154,155], catalytic oxidation [156], heterogeneous photo-Fenton $[157,158]$, photocatalytic degradation $[159,160]$, etc. The AOPs treatment methods have certain advantages. The main disadvantages of ozonation are the low solubility of ozone in water, elevated energy costs, and the formation of hazardous byproducts [149]. $\mathrm{H}_{2} \mathrm{O}_{2}$ has poor UV light absorption characteristics. Thus, this can be considered as wasting most of the light input. In the Fenton process, the production of sludge that contains iron hydroxide as a byproduct is a major drawback [161]. The main drawback of the electrochemical process is the high operating cost due to the high energy consumption [162]. Among these AOPS methods, photocatalytic degradation methods are the most employed ones to remove MB. Few new photocatalytic degradation techniques are hybrid or integrated by sonocatalysis [163], nanofiltration [141], adsorption [164], and biodegradation [165], etc. These integrated methods were found to be more efficient than a single process alone.

\section{Photodegradation of Methylene Blue}

Over the last few decades, multi-component photocatalysis of organic pollutants using semiconducting NPs has received increased attention because it is a cost-effective, environmentally-friendly, and easy technique for wastewater treatment containing hazardous pollutants [166-168]. The lower cost of catalysts and the utilization of renewable energy in this technology are much more attractive when compared to other techniques [169].

The oxidation of $\mathrm{MB}$ to $\mathrm{H}_{2} \mathrm{O}$ and $\mathrm{CO}_{2}$ through a photocatalyst is an imperative technique to remove the dye from industrial wastewater [170]. Photodegradation is an oxidation process in which the chemical breakdown of complex molecules transforms into simple, nontoxic, and lower molecular weight fragments due to light exposure [171]. This is an emerging and promising technology for waste effluent treatment, having the capability to decolourize and degrade the dye molecules into simple and nontoxic inorganic species such as $\mathrm{CO}_{2}$ and $\mathrm{H}_{2} \mathrm{O}$ [172]. The process is performed in the presence of photocatalyst, a semiconductor material activated by adsorbing photons, and can accelerate a reaction without being consumed [173].

$\mathrm{MB}$ is a representative organic dye and stable under visible light irradiation [174]. Due to its stability, it cannot be degraded efficiently just by photolysis or catalysis alone. It was reported that $7.9 \%$ of $\mathrm{MB}$ dye was removed through photolysis after $10 \mathrm{~h}$ irradiation time [175], and only $10 \%$ degradation of MB occurred after $24 \mathrm{~h}$ in the presence of a catalyst without light irradiation [176]. It was also observed that no/negligible decomposition occurred without a catalyst under visible light $[177,178]$. Similarly, no degradation was observed in the acidic and neutral medium in the dark and under sunlight irradiation without using a catalyst [179]. In the basic medium, photolysis occurs rapidly because of the formation of the hydroxyl ions, which is a key radical for dye degradation. However, raising the temperature has a negligible effect and under argon, atmosphere degradation 
completely stopped [179]. Photodegradation of MB is an efficient approach because MB can also function as a photocatalyst sensitizer [180]. The small/partial degradation observed in $\mathrm{MB}$ without catalysts might be attributed to the photosensitized phenomenon of $\mathrm{MB}$ molecules observed after irradiation with different light sources [181,182]. MB can absorb light in the region of 500-700 nm, form singlet and triplet species by electronic transition and intersystem crossing, and undergo self-decomposition to a certain extent [183]. Photolysis of MB dye proceeds in the atmospheric air, which means that the $\mathrm{O}_{2}$ is essential for the degradation. In basic media, ${ }^{\bullet} \mathrm{OH}$ radicals form through monoelectronic reduction of $\mathrm{MB}^{+}$ radicals by $\mathrm{OH}^{-}$. ${ }^{\bullet} \mathrm{OH}$ reacts with each other to produce $\mathrm{H}_{2} \mathrm{O}_{2}$, which is an important active species in degradation processes. Similarly, $\mathrm{O}_{2}$ reacts with excited $\mathrm{MB}^{*}$ radicals and forms $\mathrm{O}_{2}{ }^{\bullet-}$. These photolysis reactions of $\mathrm{MB}$ are summarized in the following Equations (1)-(3), as follow:

$$
\begin{aligned}
\mathrm{MB}^{+}+\mathrm{OH}^{-} & \rightarrow \mathrm{MB}^{*}+\mathrm{OH}^{\bullet} \\
2 \mathrm{OH}^{\bullet} & \rightarrow \mathrm{H}_{2} \mathrm{O}_{2} \\
\mathrm{MB}^{*}+\mathrm{O}_{2} & \rightarrow \mathrm{MB}^{+}+\mathrm{O}_{2}^{\bullet-}
\end{aligned}
$$

All these reactive radical species take part in the direct photolysis of MB dye [179]. Photodegradation of MB dye in \% can be calculated from the Equations (4) and (5):

$$
\begin{aligned}
& \text { Degradation rate }(\%)=\left(\frac{C_{0}-C}{C_{0}}\right) \times 100 \\
& \text { Degradation rate }(\%)=\left(\frac{A_{0}-A}{A_{0}}\right) \times 100
\end{aligned}
$$

where, $C_{0}$ represents the initial concentration of dye, $C$ stands for dye concentration after the reaction, $A_{0}$ symbolizes initial absorbance, and $A$ shows the absorbance of dye after the reaction [184]. The absorption is often measured at $664 \mathrm{~nm}$, and absorption intensity decreases with increasing irradiation time [185].

\section{Mechanism of Photodegradation of Methylene Blue}

The photodegradation of $\mathrm{MB}$ proceeds via (i) demethylation; (ii) breaking of the $\mathrm{MB}$ central aromatic ring and then the side aromatic rings; (iii) conversion of the fragments produced from the first two steps to intermediates species, such as $\mathrm{R}^{-\mathrm{NH}_{3}}{ }^{+}$, phenol, aniline and aldehydic/carboxylate species; and (iv) conversion of these intermediates to the final products, such as $\mathrm{CO}_{2}, \mathrm{H}_{2} \mathrm{O}, \mathrm{SO}_{4}{ }^{2-}$ and $\mathrm{NH}_{4}{ }^{+}$[186]. Most of the reaction intermediates come from the breakage of the aromatic ring of the $\mathrm{MB}$ dye. The fragments of dyes are degraded into further reaction intermediates, including aldehyde, carboxylic species, phenols, and amines, which are ultimately converted into $\mathrm{H}_{2} \mathrm{O}, \mathrm{CO}_{2}$, ammonium ions and sulfate ions [18].

Usually, ${ }^{\bullet} \mathrm{O}_{2}{ }^{-}$and ${ }^{\bullet} \mathrm{OH}$ radicals are responsible for the degradation of $\mathrm{MB}$ and have been determined via ESR measurements under full-spectrum irradiation in $\mathrm{H}_{2} \mathrm{O}$ and methanol. The results clearly displayed signals with intensity ratios of 1:2:2:1 and 1:1:1:1, which are the characteristic ratios for ${ }^{\bullet} \mathrm{OH}$ and ${ }^{\bullet} \mathrm{O}_{2}{ }^{-}$, respectively. The created $\mathrm{e}^{-}$and $\mathrm{h}^{+}$are transferred to the photocatalyst surface. The $\mathrm{e}^{-}$reduces $\mathrm{O}_{2}$ to superoxide radicals $\left({ }^{\bullet} \mathrm{O}_{2}{ }^{-}\right)$while the $\mathrm{h}^{+}$either oxidizes $\mathrm{H}_{2} \mathrm{O}$ to form ${ }^{\bullet} \mathrm{OH}$ or directly oxidizes $\mathrm{MB}$ dye. These reactive species $\left({ }^{\bullet} \mathrm{O}_{2}{ }^{-}, \bullet^{\bullet} \mathrm{OH}\right.$ and $\left.\mathrm{h}^{+}\right)$initiate the redox reactions and degrade $\mathrm{MB}$ dye into $\mathrm{CO}_{2}, \mathrm{H}_{2} \mathrm{O}$, or inorganic ions. Thus, the $\mathrm{MB}$ dye solution becomes colourless due to the degradation of aromatic rings [187-189]. Such a mechanism of photodegradation of MB dye can be understood from Figure 6, in which MB dye is degraded using ZnO NPs as a single-component photocatalyst [190]. Similarly, Figure 7 has provided an example of a multicomponent system consisting of $\mathrm{Fe}_{2} \mathrm{O}_{3}$ /graphene/CuO photocatalyst [191]. 


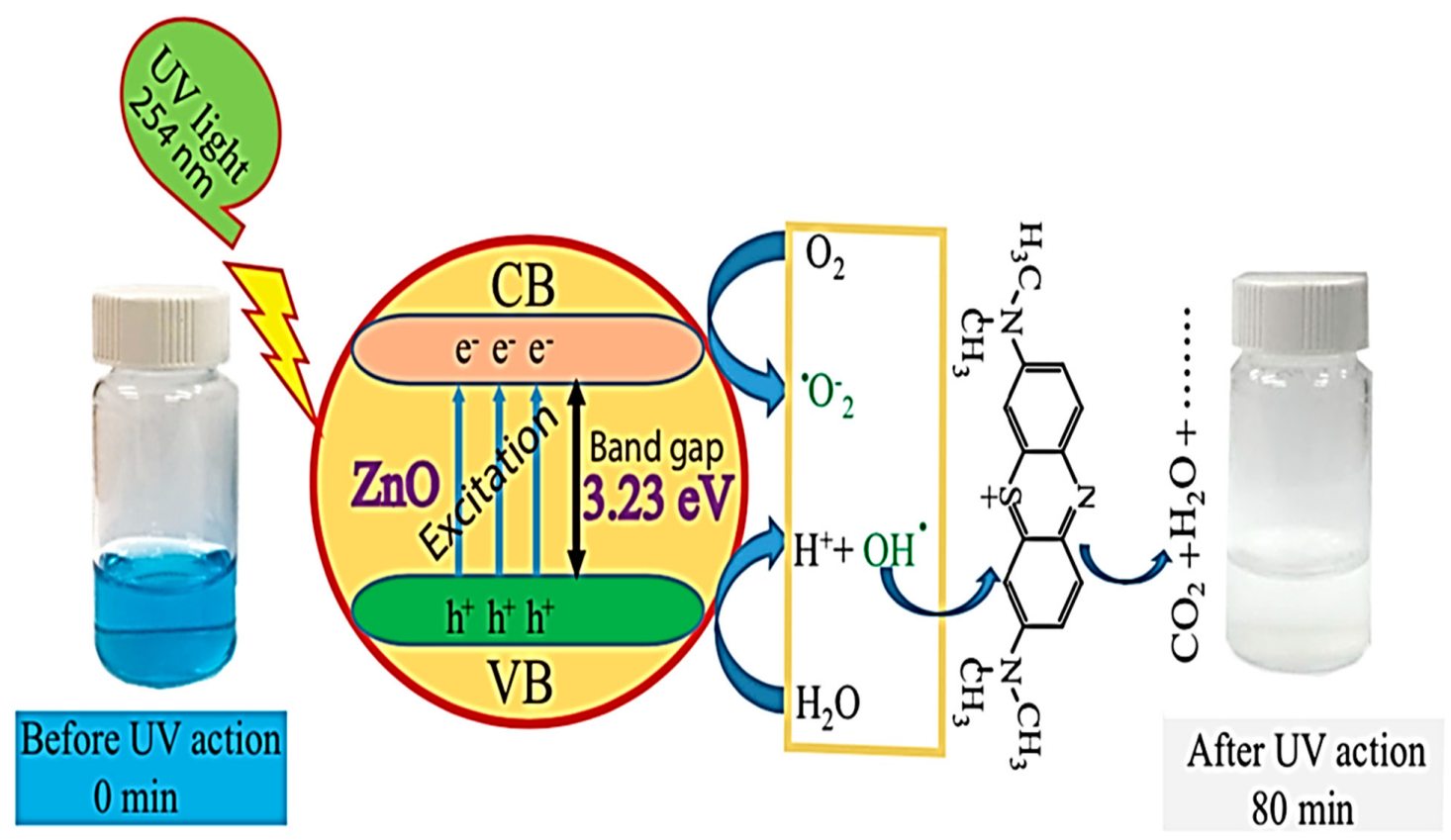

Figure 6. Proposed photocatalytic mechanism of ZnO-NPs for the catalytic degradation of MB dye [190].

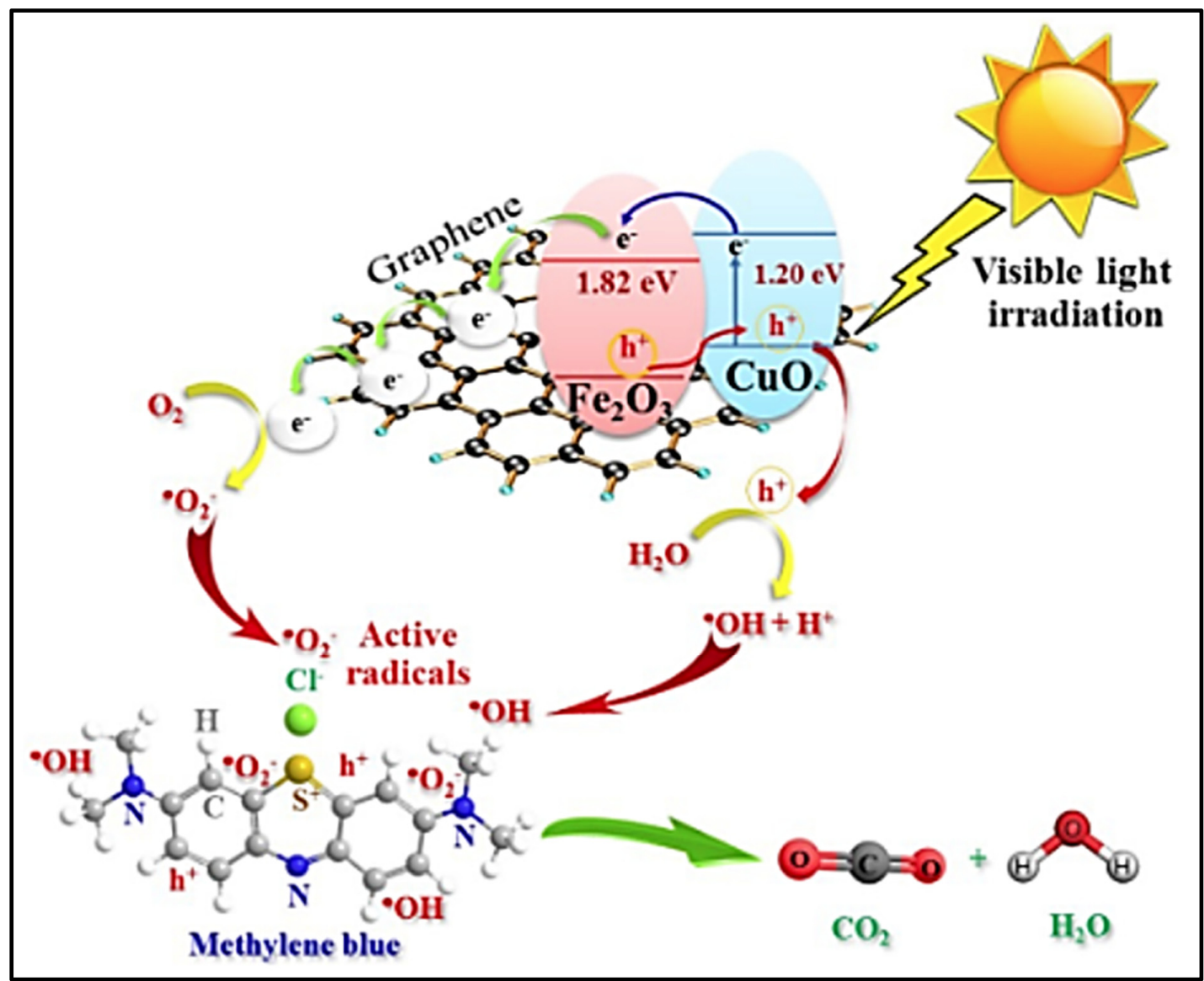

Figure 7. Postulated mechanism for the photocatalytic activity of $\mathrm{Fe}_{2} \mathrm{O}_{3}$ /graphene/CuO nanocomposite [191]. Adapted with permission from the Elsevier (License Number 5226930035146).

- $\mathrm{OH}$ has been normally recognized as the most important active species for ringopening and complete degradation of $\mathrm{MB}$ dye. The ${ }^{\bullet} \mathrm{OH}$ attacks the $\mathrm{C}-\mathrm{S}+=\mathrm{C}$ functional group, which is the initial step of MB degradation. To conserve the double bond conjugation 
that was lost through the transformation from $C-S+=C$ to $C-S(=O)-C$, the central aromatic ring containing both heteroatoms $\mathrm{S}$ and $\mathrm{N}$ is opened. Hole-induced $\mathrm{H}^{+}$plays a vital role in forming CH and NH bonds [192-194]. Such splitting of a complex molecule into smaller and highly oxidized intermediate molecules is the primary reason for dye degradation [195]. The FTIR spectroscopy studies suggest that ${ }^{\bullet} \mathrm{OH}$ radicals attack the side chains of $\mathrm{MB}$ during decomposition pathways, which leads to a demethylation process. The colour change in $\mathrm{MB}$ contributes to the protonation in the aromatic ring, and it is most likely a reversible reaction process [196]. The VB holes can also directly attack MB dye. They can degrade it [197,198] due to the high oxidation potential of holes [169], which permits direct oxidation of the dye to reactive intermediates followed by degradation [199].

\section{Parameters Affecting Methylene Blue Photodegradation}

\subsection{Effect of Irradiation Time}

The irradiation time and adsorption equilibrium between $\mathrm{MB}$ and a photocatalyst are the most critical parameters that controlled photodegradation [200]. The percentage of MB degradation is directly related to the irradiation time, which means degradation increases with increasing irradiation time [201,202]. The distinct absorption peak of MB spectra gradually decreases with the increase in reaction time. It shows a colour change from blue to colourless, and the reduction of $\mathrm{MB}$ chromophore is probably the reason for the decrease in absorption spectra $[203,204]$. The photodegradation of MB initially increases gradually by increasing irradiation time and then becomes constant after a particular time [184]. Figure 8 shows the effect of irradiation time on the photodegradation of MB, which displays the absorptive intensity of $\mathrm{MB}$ at $664 \mathrm{~nm}$, and it gradually decreases with the reaction time. The decrease in the concentration of $\mathrm{MB}$ dye in the photograph indicates that degradation increases with the irradiation time. [205].

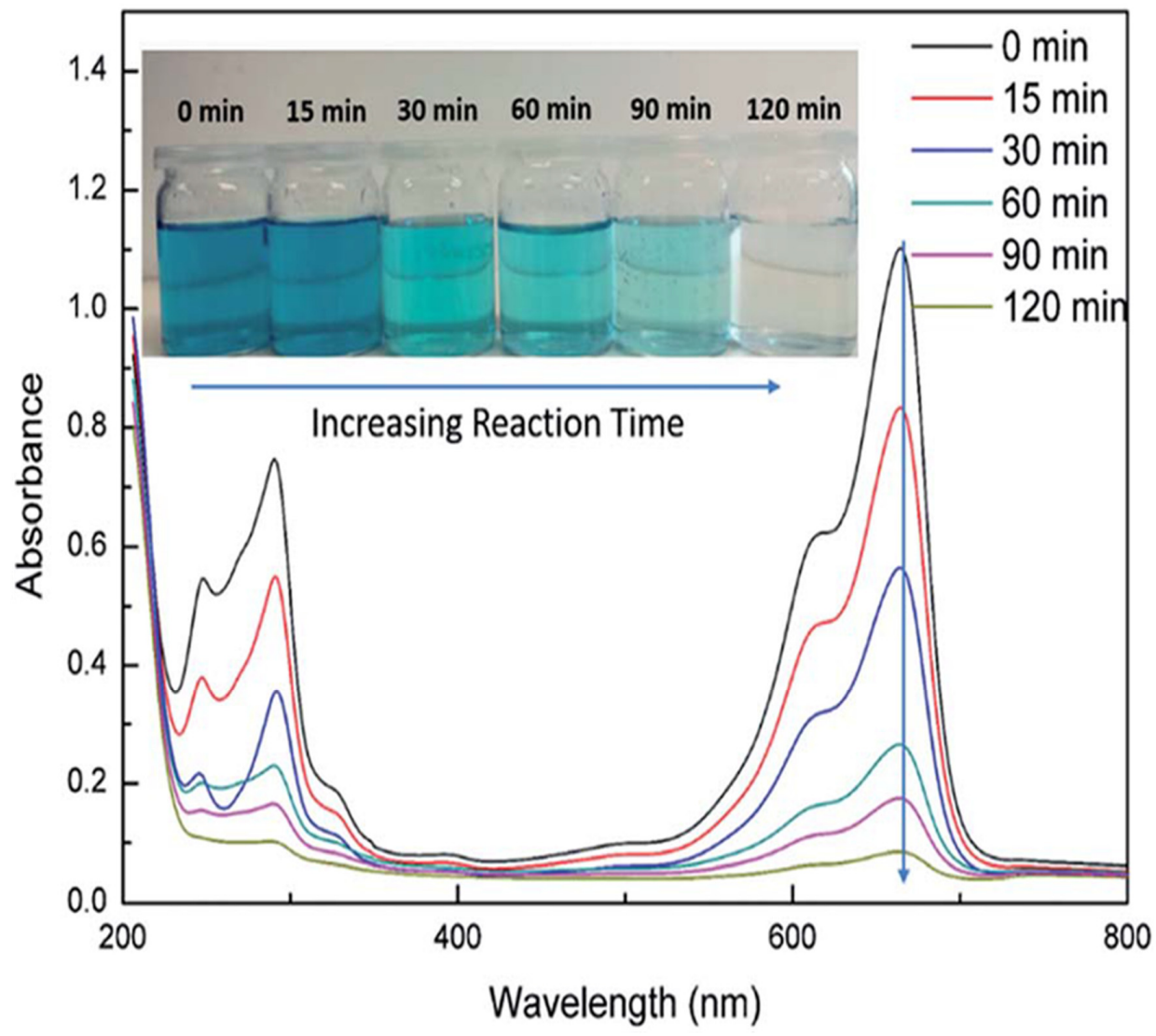

Figure 8. UV-Vis analysis of the photocatalytic degradation of $\mathrm{MB}$ by cellulose $/ \mathrm{GO} / \mathrm{TiO}_{2}$ hydrogel with the reaction time [205]. Adapted with permission from Royal Society of Chemistry (license ID 1079849-2). 


\subsection{Light Source and Intensity}

Light intensity and radiation wavelength both affect the rate of photocatalytic degradation of pollutants [206]. There are various sources of UV light such as black light tubes, fluorescent tubes, Vis white cold light tubes [207], etc., while the sources of visible light are tungsten halogen lamps (QVF135/500 W) [208] or xenon lamps (500 W) [209], etc. The more energy photons interact with the photocatalysts, the more will be the production of charge carriers and, consequently, the degradation rate will increase [18]. Solar and artificial lights have been used for the photocatalytic degradation of dyes. Still, most commonly, artificial light sources are used to maintain stable intensities and avoid clouding and other environmental issues. Graphene decorated titanium dioxide degraded $87 \% \mathrm{MB}$ dye under UV light and $40 \% \mathrm{MB}$ dye under visible light [210]. The degradation efficiency of MB is not satisfactory, and there are still limitations in terms of light source and intensity [211]. This shows that light intensity and exposure times have an immense effect on the rate of photodegradation.

\subsection{Effect of Initial Dye Concentration}

The photodegradation rate of a dye depends on its concentration, nature, and the presence of other existing compounds in the solution [212]. The adsorption capacity of MB dye is high at lower concentrations because of the availability of more active sites on the surface of the photocatalyst [206]. The photodegradation rate of MB increases by increasing initial dye concentration up to a specific limit and then decreases with further increasing dye concentration [213]. The initial increase in the MB dye degradation rate with increasing initial dye concentration might be due to the rise in the reaction probability between the dye molecules and the ${ }^{\bullet} \mathrm{OH}$ radical [214]. Using $\mathrm{TiO}_{2}$ as a photocatalyst, Pandey et al. [215] observed that increasing the $\mathrm{MB}$ concentration beyond the limit $\left(3.00 \times 10^{-6} \mathrm{M}\right)$ causes retardation of reaction due to the increased collisions between dye molecules and decreased collisions between the dye and the $\bullet \mathrm{OH}$. Arumugam and Choi [45] also observed such results using a $\mathrm{BiVO}_{4}$ photocatalyst. They explained that dye molecule adsorption on the photocatalyst surface and the rate of hydroxyl radical formation is high at a lower concentration. The slower degradation rate at higher concentrations is because of the intermediate products of the MB degradation, which have lower light absorbance and would compete with MB for reaction with hydroxyl radicals and thus lower MB degradation rates [216]. The higher $\mathrm{MB}$ concentration might serve as an inner filter shunting the light photons away from the surface of the photocatalyst, making oxidative free radicals non-available [217]. It is suggested that the lower photodegradation of MB at higher concentration occurs because of the covering of active sites of photocatalysts by higher dye molecules adsorption, which suppresses the generation of active ${ }^{\bullet} \mathrm{OH}$ radicals and increases the screening effect of UV light [218].

\subsection{The $p H$ Effect}

The $\mathrm{pH}$ plays a vital role in the characteristics of dyes and the reaction mechanisms, including hydroxyl radical attack, direct oxidation by the $\mathrm{h}^{+}$, and immediate reduction by the conducting band $\mathrm{e}^{-}$[219]. The surface charge of the adsorbent (catalyst) also varies with changing the $\mathrm{pH}$ value [220]. $\mathrm{MB}$ is a cationic dye and will adsorb on a highly negatively charged photocatalyst [221]. The photodegradation of MB could be tuned with the $\mathrm{pH}$ of the medium [222]. In a basic medium, the photocatalyst tends to acquire a negative charge that results in increased adsorption of positively charged dyes because of the rising electrostatic attraction [223]. At lower $\mathrm{pH}$ (acidic media), $\mathrm{H}^{+}$as the dominant species competes with the cationic MB dye, which decreases the adsorption of the MB molecules on the surface of the photocatalyst. The non-adsorption of $\mathrm{MB}$ on the photocatalyst surface reduces the reaction between the ${ }^{\bullet} \mathrm{OH}$ and $\mathrm{MB}$. At higher $\mathrm{pH}$, there is no competition between $\mathrm{OH}^{-}$ and $\mathrm{MB}$, as $\mathrm{OH}^{-}$will be repelled by the negatively charged surface of the photocatalyst and will remain in the solution in a large quantity [224,225]. Some photocatalysts such as $\mathrm{ZnO}$ may dissolve at lower $\mathrm{pH}$, which decreases MB degradation [226]. The adsorption 
of $\mathrm{MB}$ on the surface of $\mathrm{TiO}_{2}$ is maximum in the basic medium as it acquires a negatively charged surface, which causes an increase in the electrostatic attraction between the $\mathrm{TiO}_{2}$ particles and the MB molecules [227].

\subsection{Effect of Oxidants}

The practical way to increase the photodegradation of $\mathrm{MB}$ is to add a strong oxidant [228]. $\mathrm{H}_{2} \mathrm{O}_{2}$ increases the formation rate of hydroxyl radicals and enhances the degradation of compounds at low concentrations. This is due to the efficient generation of $\bullet \mathrm{OH}$ and inhibition of electron-hole pair recombination, as $\mathrm{H}_{2} \mathrm{O}_{2}$ is an electron acceptor $[229,230]$. Hydrogen peroxide is considered one of the most potent oxidizing potential catalysts and produces $2 \mathrm{~mol}$ of the ${ }^{\bullet} \mathrm{OH}\left(\mathrm{H}_{2} \mathrm{O}_{2}+\mathrm{hv}=2^{\bullet} \mathrm{OH}\right)$, followed by interaction with dye molecules [231]. The efficiency of $\mathrm{MB}$ degradation increases by increasing $\mathrm{H}_{2} \mathrm{O}_{2}$ amount up to a certain extent and then decreases, which might be due to recombination caused by hydroxyl radicals and the scavenging effect of $\mathrm{H}_{2} \mathrm{O}_{2}$ [232]. At higher concentration, $\mathrm{H}_{2} \mathrm{O}_{2}$ can scavenge ${ }^{\bullet} \mathrm{OH}$ to form ${ }^{\bullet} \mathrm{OOH}$, as shown in Equation (6), which have much lower oxidation capability [233]. Air and $\mathrm{KMnO}_{4}$ are also used as potential oxidizing agents for the photodegradation of $\mathrm{MB}[234,235]$. Citrate ions generate $\mathrm{H}_{2} \mathrm{O}_{2}$ via its photolysis and cause a slight increase in the decolourization of MB [236].

$$
\mathrm{H}_{2} \mathrm{O}_{2}+{ }^{\bullet} \mathrm{OH} \rightarrow \mathrm{H}_{2} \mathrm{O}+{ }^{\bullet} \mathrm{OOH}
$$

\subsection{Effect of Radical Scavengers and Ions}

In the photodegradation process, hole, hydroxyl and superoxide radicals are the key reactive species participating in organic pollutants degradation [237]. Several radicals' scavengers are reported to understand the mechanism and the primary active species responsible for the photodegradation of MB [238]. These radicals include ammonium oxalate $\left(\mathrm{h}^{+}\right), t$-butanol $\left({ }^{\bullet} \mathrm{OH}\right)$, and 1,4-benzoquinone $\left({ }^{\bullet} \mathrm{O}_{2}{ }^{-}\right)$[239]. Salgado and Valentini [240] used $\mathrm{SiO}_{2} @ \mathrm{TiO}_{2}$ hybrid spheres as a photocatalyst for $\mathrm{MB}$ degradation and applied t-butyl alcohol ( ${ }^{\bullet} \mathrm{OH}$ scavenger), benzoquinone $\left({ }^{\bullet} \mathrm{O}_{2}{ }^{-}\right.$scavenger) and ethylenediamine tetraacetic acid $\left(\mathrm{h}^{+}\right.$scavenger). It was observed that $\mathrm{t}$-butyl alcohol significantly suppressed the photocatalytic efficiency than other scavengers. They thus suggested that ${ }^{\bullet} \mathrm{OH}$ mainly promoted MB degradation. Lee and Park [241] employed $\alpha-\mathrm{Fe}_{2} \mathrm{O}_{3} / g-\mathrm{C}_{3} \mathrm{~N}_{4}$ nanofilm. They documented the same results that tert-butyl alcohol significantly lowered the degradation rate when $\mathrm{H}_{2} \mathrm{O}_{2}$ was added, indicating that the ${ }^{\bullet} \mathrm{OH}$ generated by the Fenton reaction is the significant reactant in the $\mathrm{MB}$ degradation. Using different scavengers, several researchers also reported that ${ }^{\bullet} \mathrm{OH}$ is the main species in MB degradation [242-245]. Bicarbonate is a well-known radical scavenger, but under certain conditions, it enhances the degradation of certain pollutants, as also observed for MB. The reason is that bicarbonate radicals are more stable than ${ }^{\bullet} \mathrm{OH}$, and their oxidation ability is relatively high, making the lifetime of bicarbonate radicals longer than that of ${ }^{\bullet} \mathrm{OH}$ and resulting in an enhanced degradation performance [246]. Other important ${ }^{\bullet} \mathrm{OH}$ scavengers reported in the literature for photodegradation of MB are acetonitrile [192] and $\mathrm{CaCO}_{3}$ [247].

Inorganic anion tends to coexist with organic pollutants in wastewater effluent and can influence the separation and purification substances represented in the wastewater treatment [248]. The effects of various inorganic anions on the photodegradation of MB in the presence of different photocatalysts are summarized in Table 2. 
Table 2. The effect of inorganic anions on photodegradation of MB.

\begin{tabular}{|c|c|c|c|c|c|c|}
\hline Photocatalyst & Inorganic Anions & Positive Effect & Negative Effect & Dual Effect & Negligible Effect & Reference \\
\hline $\begin{array}{l}\mathrm{Au}-\mathrm{Fe}_{3} \mathrm{O}_{4} / \\
\text { graphene composites }\end{array}$ & $\begin{array}{l}\mathrm{NaCl}, \mathrm{Na}_{2} \mathrm{SO}_{4}, \mathrm{NaH}_{2} \mathrm{PO}_{4} \\
\mathrm{NaNO}_{3} \text {, and } \mathrm{Na}_{2} \mathrm{CO}_{3}\end{array}$ & & $\begin{array}{l}\mathrm{SO}_{4}{ }^{2-}, \mathrm{Cl}^{-}, \\
\mathrm{H}_{2} \mathrm{PO}_{4}^{-}, \mathrm{NO}_{3}{ }^{-}, \\
\mathrm{CO}_{3}{ }^{2-}\end{array}$ & & $\mathrm{Na}^{+}$ & [248] \\
\hline $\mathrm{Ag}_{3} \mathrm{PO}_{4}$ & $\begin{array}{l}\mathrm{NO}_{3}^{-}, \mathrm{OH}^{-}, \mathrm{NO}_{2}{ }^{-}, \mathrm{HCO}_{3}{ }^{-}, \\
\mathrm{Cl}^{-}, \mathrm{Br}^{-}, \mathrm{CO}_{3}{ }^{2-}, \mathrm{SO}_{4}{ }^{2-}, \\
\mathrm{SO}_{3}{ }^{2-}, \mathrm{S}^{2-} \text { and } \\
\mathrm{PO}_{4}{ }^{3-}\end{array}$ & $\begin{array}{l}\mathrm{OH}^{-}, \mathrm{Cl}^{-}, \mathrm{Br}^{-}, \\
\mathrm{HCO}^{-}, \mathrm{CO}_{3}{ }^{2-}, \\
\mathrm{SO}_{4}{ }^{2-}, \mathrm{SO}_{3}{ }^{2-}, \mathrm{S}^{2-}\end{array}$ & $\mathrm{NO}_{2}^{-}$ & $\begin{array}{l}\mathrm{HCO}_{3}{ }^{-}, \mathrm{Cl}^{-}, \mathrm{SO}_{3}{ }^{2-}, \\
\mathrm{PO}_{4}{ }^{3-}, \mathrm{Br}^{-}\end{array}$ & $\mathrm{NO}_{3}^{-}$ & [249] \\
\hline $\mathrm{ZnFe}_{2} \mathrm{O}_{4}$ & $\mathrm{SO}_{4}{ }^{2-}, \mathrm{NO}_{3}{ }^{-}, \mathrm{Cl}^{-}, \mathrm{CO}_{3}{ }^{2-}$ & & $\begin{array}{l}\mathrm{SO}_{4}{ }^{2-}, \mathrm{NO}_{3}{ }^{-}, \mathrm{Cl}^{-}, \\
\mathrm{CO}_{3}^{2-}\end{array}$ & & & [250] \\
\hline $\begin{array}{l}\text { cerium-doped } \\
\mathrm{SiO}_{2} / \mathrm{TiO}_{2}\end{array}$ & $\mathrm{NO}_{3}{ }^{-}, \mathrm{SO}_{4}{ }^{2-}, \mathrm{Cl}^{-}$ & & $\mathrm{NO}_{3}^{-}, \mathrm{SO}_{4}{ }^{2-}, \mathrm{Cl}^{-}$ & & & [251] \\
\hline silver ion-doped $\mathrm{TiO}_{2}$ & $\mathrm{Cl}^{-}, \mathrm{NO}_{3}{ }^{-}, \mathrm{SO}_{4}{ }^{2-}, \mathrm{CO}_{3}{ }^{2-}$ & $\begin{array}{l}\mathrm{Cl}^{-}, \mathrm{NO}_{3}{ }^{-}, \mathrm{SO}_{4}{ }^{2-}, \\
\mathrm{CO}_{3}{ }^{2-}\end{array}$ & & & & [252] \\
\hline
\end{tabular}

Conclusively, photocatalyst's type and concentration selectively control radical production and kinetics during photodegradation.

\section{Degradation Products of Methylene Blue, Its Identification, and Reaction Pathways}

The reactive radicals generated in the single-component and multicomponent photocatalysis are $\mathrm{h}^{+},{ }^{\bullet} \mathrm{OH}$, and ${ }^{\bullet} \mathrm{O}_{2}{ }^{-}$oxidize $\mathrm{MB}$ dye into $\mathrm{CO}_{2}, \mathrm{H}_{2} \mathrm{O}$, and other degradation products [253]. The degradation of $\mathrm{MB}$ leads to the formation of harmless $\mathrm{CO}_{2}$ and conversion of $\mathrm{N}$ and $\mathrm{S}$ heteroatoms into inorganic ions, such as nitrate, ammonium, and sulfate ions, respectively [194]. The decrease in the maximum absorption peak $(664 \mathrm{~nm})$ intensity of MB indicates that the chromophoric group of the MB molecule is completely removed [254]. When the characteristic peak position of MB absorption spectrum centred at $664 \mathrm{~nm}$ remains the same during the entire experiment with a decrease in intensity, it indicates the absence of any other chromophore molecules as a by-product [255]. The complete degradation of MB without any intermediate formation can be examined by the disappearance of the $\lambda_{\max }$ peak $(662 \mathrm{~nm})$ without the appearance of other peaks in the UV-vis spectra [256]. Zhou et al. [257] observed that the exhibited bands at 465 and $292 \mathrm{~nm}$ in the UV-vis spectra decrease rapidly and disappear after $40 \mathrm{~min}$ without the appearance of new absorption bands in the spectra. They indicated that the heteropolyaromatic linkages and benzene rings of MB were likely to be depleted as the dye was completely degraded. The blue shifts in the UV spectra of MB indicate the formation of by-products, such as Azure A, Azure B, Azure C, and Thionine [258]. The formation of these compounds occurs through the demethylation of MB during the photodegradation process [259]. Aniline was observed as a degradation product of $\mathrm{MB}$ as a small peak was observed corresponding to $\mathrm{m} / \mathrm{z}=121.1796$, which is assigned to aniline, using $\mathrm{Cu}_{9} \mathrm{~S}_{5}$ as photocatalyst [260]. Mondal et al. [67] proposed that the active radicals, such as $\mathrm{OH}^{\bullet}$ and $\mathrm{HO}_{2}{ }^{\bullet}$, first degrade the $\mathrm{N}-\mathrm{CH}_{3}$ bond, and then $-\mathrm{CH}_{3}$ is oxidized to $\mathrm{HCHO}$ or $\mathrm{HCOOH}$. The active radicals then break the thionine molecule's $\mathrm{C}-\mathrm{S}$ and $\mathrm{C}-\mathrm{N}$ bonds and produce relatively unstable smaller organic by-products. These reactions continue until the $\mathrm{MB}$ degrades completely to smaller inorganic molecules, such as $\mathrm{CO}_{2}, \mathrm{H}_{2} \mathrm{O}, \mathrm{Cl}^{-}, \mathrm{SO}_{4}{ }^{2-}$ and $\mathrm{NO}_{3}$. They presented the possible reactions steps involved in Figure 9. In the ESI-MS spectrum, the presence of peaks at lower $\mathrm{m} / \mathrm{z}$ ratio, i.e., 114, $122,142,150,159$, confirmed successful and total degradation of the MB molecule into smaller fragments [261]. In a study, intermediates and the final products generated were detected using IC, GC-MS, and LC-MS technologies, and the MB degradation pathway was proposed. The authors concluded that most of the $\mathrm{Cl}^{-}$might be ionized during the dissolution of $\mathrm{MB}$ and exist in the independent state. $\mathrm{N}-\mathrm{CH}_{3}$ with the lowest bond energy of $70.8 \mathrm{kcal} / \mathrm{mol}$ is first broken, and $-\mathrm{CH}_{3}$ is oxidized to $\mathrm{HCOOH}$ or $\mathrm{HCHO}$. N- $\mathrm{CH}_{3}$ and $\mathrm{C}-\mathrm{N}$ are broken after the oxidation of $\mathrm{Cl}-\mathrm{S}$ to $\mathrm{S}=\mathrm{O}$, and the $\mathrm{S}-\mathrm{C}$ bond in the remaining structure is split to form phenol and aniline-2-sulfonic acid. These organic intermediates in solution were further oxidized until they were finally transformed into $\mathrm{CO}_{2}, \mathrm{H}_{2} \mathrm{O}, \mathrm{Cl}^{-}$, $\mathrm{SO}_{4}{ }^{2-}$, and $\mathrm{NO}_{3}{ }^{-}$[262]. Another study indicates that ${ }^{\circ} \mathrm{OH}$ and $\mathrm{H}_{2} \mathrm{O}_{2}$ may attract towards the cationic sulfur group and heteroaromatic ring of the $\mathrm{MB}$ that induces the opening 
of the central aromatic ring. Thus producing sulfoxide and hydroxylated intermediate products. These sulfoxide groups may further oxidize to sulfone and cause the dissociation of the two rings. Finally, these aromatic compounds decomposed and formed volatile low molecular weight compounds such as $\mathrm{CO}_{2}, \mathrm{H}_{2} \mathrm{O}, \mathrm{NH}^{4+}, \mathrm{NO}_{3}{ }^{-}$and $\mathrm{SO}_{4}{ }^{2-}$ ions. The whole systematic degradation process is summarized in Figure 10 [263]. It was also proposed that $\mathrm{N}-\mathrm{CH}_{3}$ terminal bonding of $\mathrm{MB}$ is the first broken bonding, and $\mathrm{CH}_{3}$ is oxidized to $\mathrm{HCOOH}$ or $\mathrm{HCHO}$. The remaining $\mathrm{C}-\mathrm{N}$ and $\mathrm{C}-\mathrm{S}$ bonding are continuously broken to form the single ring structures and then finally oxidized to ions such as $\mathrm{NO}_{3}{ }^{-}, \mathrm{SO}_{4}{ }^{2-}, \mathrm{H}_{2} \mathrm{O}$, and $\mathrm{CO}_{2}$ [264]. Similarly, the disappearance of FTIR individual characteristics peaks (Table 1) in photocatalytically treated MB solution indicates the removal of the MB molecule, while the appearance of any new peaks may be due to the formation of mineralized ions [70,265]. In the same way, the decrease in the total organic carbon (TOC) values after photodegradation reactions show the mineralization degree of the MB $[266,267]$. The HPLC analysis of MB dye at different intervals of reaction time represents chromatograms for azure A, azure $B$, azure $C$, and Thionine as intermediates products [268].<smiles>CN(C)c1ccc2nc3ccc(=[N+](C)C)cc-3sc2c1</smiles>

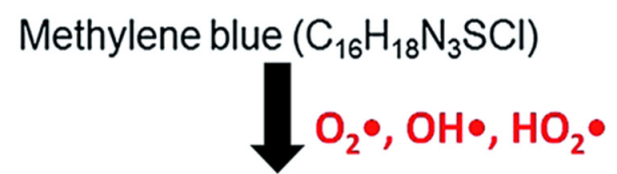<smiles></smiles>

Thionine acetate: $\mathrm{R}^{1}=\mathrm{NH}_{2}, \mathrm{R}^{2}=\mathrm{NH}_{2}$

Azure A $\quad: \mathrm{R}^{1}=\mathrm{NMe}_{2}, \mathrm{R}^{2}=\mathrm{NH}_{2}$

Azure B $\quad: \mathrm{R}^{1}=\mathrm{NMe}_{2}, \mathrm{R}^{2}=\mathrm{NHMe}$

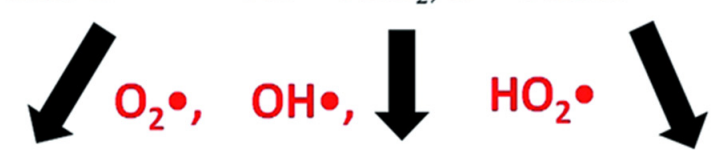<smiles>CC(=O)Nc1ccc(O)cc1</smiles>

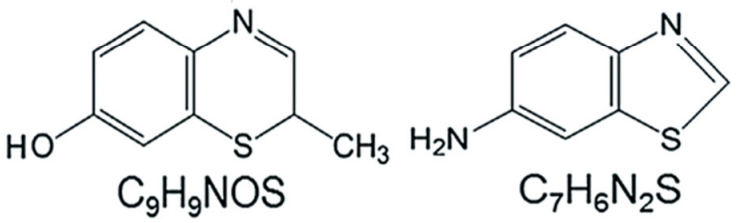

$1 \mathrm{O}_{2}{ }^{\circ}$<smiles>O=CC1CC1(O)OO</smiles>

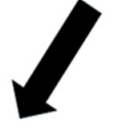

\section{Single ring structure product and finally degraded to $\mathrm{CO}_{2}, \mathrm{H}_{2} \mathrm{O}, \mathrm{Cl}^{-}, \mathrm{SO}_{4}{ }^{2-}$ and $\mathrm{NO}_{3}$}

Figure 9. Probable reaction steps of MB photocatalytic degradation [67]. Adapted with permission from the Royal Society of Chemistry (license ID 1079849-3). 


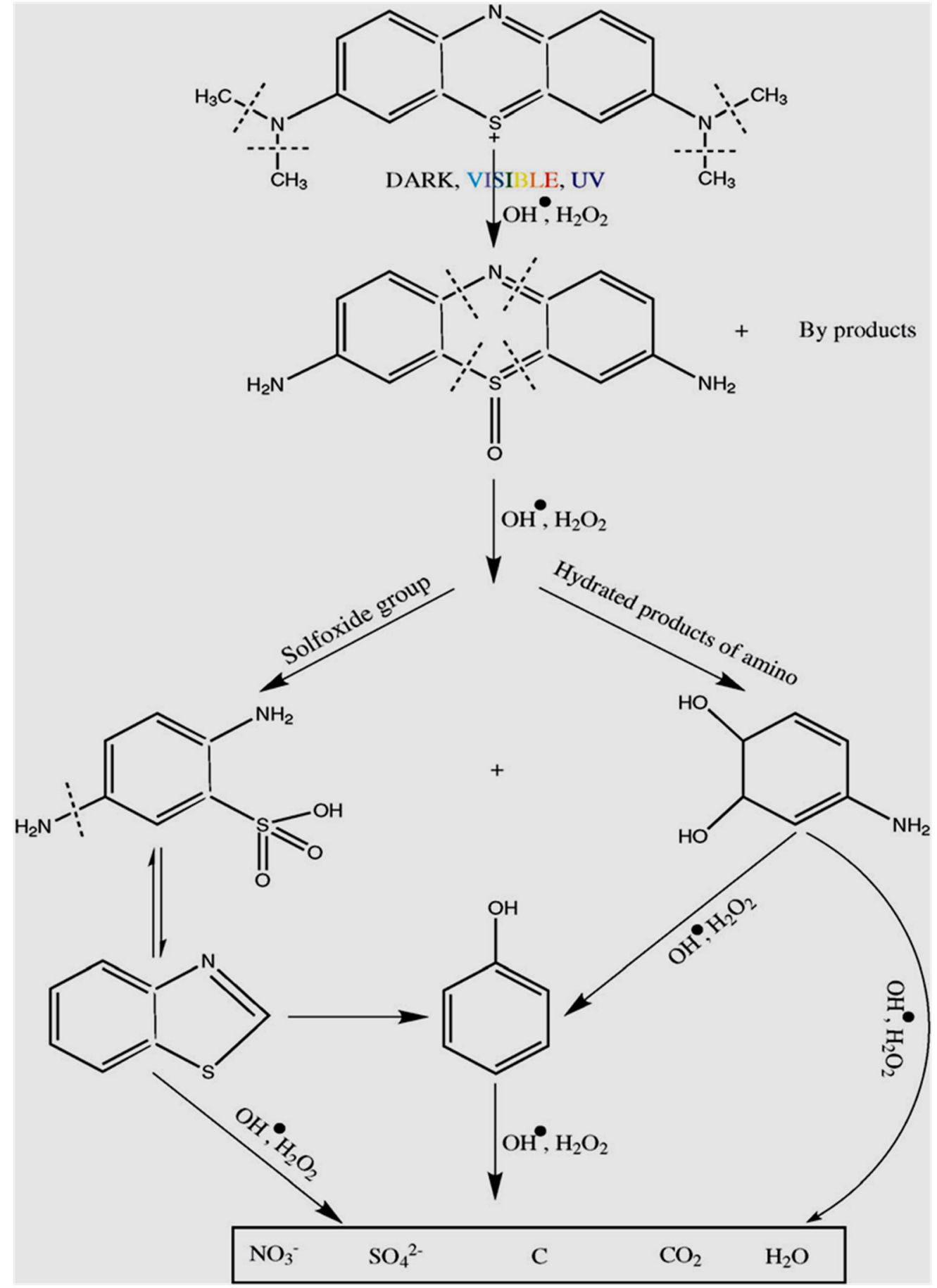

Figure 10. Proposed MB degradation pathway during the photocatalytic process [263]. Adapted with permission from Royal Society of Chemistry (license ID 1080130-1).

\section{Role of Catalysts}

The photodegradation efficiency of MB is significantly influenced by the type of the catalyst and its concentration. As mentioned above, many single-component and multicomponent photocatalysts have been successfully employed to achieve maximum degradation efficiency. Some examples are $\mathrm{ZnS}$ [33], $\mathrm{TiO}_{2}$ [34,35], $\mathrm{ZnO}$ [36], hematite [37-39], plasmonic metals (such as gold, silver, platinum) [40,41,269], metal vanadates (those of $\mathrm{Bi}$, $\mathrm{Ni}, \mathrm{Cu}, \mathrm{Zn}$, etc.) [43-47], and carbon-based catalysts such as graphene and its oxides, and carbon nitrides, [40,41]. These systems have demonstrated high efficacy in oxidizing MB through redox reactions. 
For the single component photocatalyst such as $\mathrm{TiO}_{2}$ [35], the redox reactions are initiated by irradiating the photocatalyst with light of suitable photon energy (of energy $\geq$ bandgap of the photocatalyst). This leads to exciting electron from the valence band to the conduction band of the photocatalyst, generating electon-hole pairs. At the photocatalyst surface, the electrons and holes participate in the reduction and oxidation reactions, respectively. The reduction reaction of the conduction band electrons with oxygen produces superoxide anions, while the oxidation reaction of the valence band hole with water molecules produces hydroxyl radicals. The produced superoxide anions and hydroxel radicals can degrade $\mathrm{MB}$. However, the single component photocatalyst such as $\mathrm{TiO}_{2}$ or $\mathrm{ZnO}$ [36] suffers from some drawbacks, including the wide bandgap, and the inability to absorb the visible light, which limits its photocatalytic applications to the UV region of the sunlight spectrum. Moreover, the high recombination rate of the photoexcited electron-hole pairs in the single component photocatalyst weakens the dye degradation rate [26-28]. As a result, many studies have been reported on the surface modification of single component photocatalysts such as addition of noble metals, graphene, or carbon to reduce their bandgaps, and electron-hole recombination and hence enhance their photocatalytic performance [270].

Nevertheless, preparing an efficient, wide bandgap photocatalyst is still challenging. Therefore, an efficient strategy for crafting a highly effective photocatalyst is designing a multi-component photocatalyst in which a narrow bandgap photocatalyst composites the wide bandgap photocatalyst. Such a design enhances the absorption of the visible region of the sunlight spectrum, reduces the electron-hole recombination rate, and enhances photocatalytic activity. Table 3 provides selected examples of efficient multi-component photocatalysts for MB degradation from wastewater. On the other hand, the following parameters of the photocatalyst also need to be manipulated and optimized to promote degradation efficiency:

1. Particle size: when the particle size is reduced to the nanoscale level, the specific surface area and the number of the active sites increases.

2. Morphology: morphology is a key that provides the exposed area to sunlight. It is reported that nano rod-like $\mathrm{ZnO}$ structures form a high amount of reactive species due to strong absorption and lower recombination [271].

3. Crystallinity: higher crystallinity leads to fewer defects for the recombination of photoexcited electron-hole pairs, and hence improves the overall photocatalytic activity of the catalyst [272].

4. The high surface area associated with more active sites, and dye adsorption capacity.

5. Facet tuning for specific wavelength absorption as in the case of copper and $\mathrm{TiO}_{2}$ based materials that are widely used in relevant applications [273,274].

6. Kinetic directing catalysts, which produce the desired products from the recycled MB degraded products for use, are also important.

Considering these objectives, various parameters of the catalyst need to be manipulated and optimized, including the nanoscale particle size, desirable morphology (1D, 2D or 3D), and crystallinity. A wide range of literature is available on 1D photocatalysts [275], 2-D photocatalysts such as graphene and carbon nitrides [276,277], and 3D materials with octahedral morphologies $[273,278]$. Table 3 provides selected examples of efficient multi-component photocatalysts for MB degradation from wastewater. 
Table 3. Photodegradation of MB over various photocatalysts.

\begin{tabular}{|c|c|c|c|c|c|}
\hline $\begin{array}{l}\text { Optimized Material } \\
\text { and Morphology }\end{array}$ & Synthesis Method & Light Source & $\begin{array}{l}\text { \%MB } \\
\text { Degraded@Time }\end{array}$ & Favourable Features & Ref \\
\hline $\begin{array}{l}\beta- \\
\mathrm{Cu}_{2} \mathrm{~V}_{2} \mathrm{O}_{7} / \mathrm{Zn}_{2} \mathrm{~V}_{2} \mathrm{O}_{6} \\
(1 \mathrm{wt} \%: 5 \mathrm{wt} \%) \\
\text { Layered morphology }\end{array}$ & $\begin{array}{l}\text { Ultrasonic assisted } \\
\text { hydrothermal } \\
\text { synthesis }\end{array}$ & 300 Xenon Lamp & 98.7\%@65 min & $\begin{array}{l}\text { Due to the layered morphology of } \\
\mathrm{Cu}_{2} \mathrm{~V}_{2} \mathrm{O}_{7} \text {, the } \mathrm{Zn}_{2} \mathrm{~V}_{2} \mathrm{O}_{6} \text { pelets are } \\
\text { distributed evenly, hence facilitate } \\
\text { the charge transfer. A large surface } \\
\text { area provides more catalytic sites } \\
\text { and exposure to light. }\end{array}$ & [43] \\
\hline $\begin{array}{l}\mathrm{CuO} / \mathrm{Bi}_{2} \mathrm{O}_{3} \\
\text { nanocomposite }\end{array}$ & $\begin{array}{l}\text { Impregnation } \\
\text { calcination method }\end{array}$ & UV-C irradiation & 88.32\%@120 min & $\begin{array}{l}\text { Probably due to the synergistic } \\
\text { effect between the components of } \\
\text { the nanocomposite }\end{array}$ & [279] \\
\hline $\begin{array}{l}\mathrm{ZnO}-\mathrm{NR} / \mathrm{ACF} \\
\text { nanocomposites }\end{array}$ & $\begin{array}{l}\text { Hydrothermal } \\
\text { method }\end{array}$ & UV irradiation & 99\%\%@120 min & $\begin{array}{l}\text { Synergistic effects between } \mathrm{ZnO} \\
\text { nanorods and activated carbon } \\
\text { fibers (ACFs) }\end{array}$ & {$[280]$} \\
\hline $\begin{array}{l}\mathrm{SnO}_{2} \text {-bentonite } \\
\text { nanocomposites }\end{array}$ & Green synthesis & Solar irradiation & 100\%@300 min & $\begin{array}{l}\text { Efficient dye adsorption on } \\
\text { bentonite and high surface of } \\
\text { immobilized } \mathrm{SnO}_{2} \text { on bentonite } \\
\text { surface }\end{array}$ & [281] \\
\hline 5\% PTh/ZnO & $\begin{array}{l}\text { Sol-gel and oxidative } \\
\text { polymerization } \\
\text { techniques }\end{array}$ & $\begin{array}{l}250 \text { W high-pressure } \\
\text { mercury lamp }\end{array}$ & 95\%@180 min & $\begin{array}{l}\text { Perfect synchronization and } \\
\text { synergistic effect of both PTh and } \\
\mathrm{ZnO}\end{array}$ & [282] \\
\hline $\begin{array}{l}\mathrm{TiO}_{2} / \text { Seashell } \\
\text { composites }(23.4 \% \\
\text { TCAS) }\end{array}$ & $\begin{array}{l}\text { Simple grinding and } \\
\text { calcination, } \\
\text { followed by the } \\
\text { sol-gel process }\end{array}$ & Natural sunlight & 100\%@140 min & $\begin{array}{l}\text { The elements presents in abalone } \\
\text { shell doped into the substitutional } \\
\text { sites of } \mathrm{TiO}_{2} \text { and act as } \\
\text { semiconductors that improved the } \\
\text { charge separation efficiency of } \mathrm{TiO}_{2} \text {. }\end{array}$ & [283] \\
\hline $\begin{array}{l}\gamma-\mathrm{Fe}_{3} / \\
\mathrm{Fe}_{3} \mathrm{O}_{4} / \mathrm{SiO}_{2}(\mathrm{Ar} \\
\text { modified })\end{array}$ & $\begin{array}{l}\text { Single-stage } \\
\text { heat-treatment } \\
\text { process }\end{array}$ & UV-light & 87.5\%@120 min & $\begin{array}{l}\text { Combined effects of structure } \\
\text { defects, oxygen vacancies, } \\
\text { and the formed carbon sheets after } \\
\text { PVA decomposition }\end{array}$ & [284] \\
\hline $\begin{array}{l}70 \% \mathrm{CeO}_{2} / \mathrm{g}-\mathrm{C}_{3} \mathrm{~N}_{4} \\
\text { Z-scheme } \\
\text { heterojunction }\end{array}$ & Ball milling & UV light irradiation & 90.1\%@180 min & $\begin{array}{l}\text { Stronger UV light response, higher } \\
\text { charge carrier separation efficiency } \\
\text { and the synergy } \\
\text { between adsorption and } \\
\text { photocatalysis. }\end{array}$ & [285] \\
\hline $\begin{array}{l}\mathrm{g}-\mathrm{C}_{3} \mathrm{~N}_{4} / \mathrm{Ca}_{2} \mathrm{Fe}_{2} \mathrm{O}_{5} \\
\text { heterostructures }\end{array}$ & $\begin{array}{l}\text { Solid-state reaction } \\
\text { route }\end{array}$ & Natural sunlight & 95.4\%@70 min & $\begin{array}{l}\text { Enhance photodegradation efficient } \\
\text { due to the mitigation of } \\
\text { recombination of photogenerated } \\
\text { charge carriers by Type-II } \\
\text { heterojunction }\end{array}$ & [286] \\
\hline $\begin{array}{l}\text { Flower-like } \\
\mathrm{Bi}_{2} \mathrm{O}_{4} / \mathrm{ZnO} \\
\text { heterojunction }\end{array}$ & $\begin{array}{l}\text { Hydrothermal } \\
\text { method }\end{array}$ & $\begin{array}{l}\text { Xenon lamp of power } \\
300 \mathrm{~W}\end{array}$ & 98.5\%@30 min & $\begin{array}{l}\text { The product exibited prferable } \\
\text { morphology for the photocatalytic } \\
\text { activity }\end{array}$ & [287] \\
\hline $\begin{array}{l}\text { Ternary } \\
\mathrm{MoS}_{2} / \mathrm{Bi}_{2} \mathrm{~S}_{3} / \mathrm{TiO}_{2} \\
\text { heterostructure }\end{array}$ & $\begin{array}{l}\text { Microwave-assisted } \\
\text { hydrothermal } \\
\text { method }\end{array}$ & $250 \mathrm{~W}$ Xenon lamp & 99\%@4 min & $\begin{array}{l}\text { Ultrafst } \mathrm{Mb} \text { phododegradation is } \\
\text { duto introducing multiple } \\
\text { pathways of electrons transfer that } \\
\text { efficiently suppressed the } \\
\text { photoelectrons-holes recombination } \\
\text { in the heterostructured composite }\end{array}$ & [288] \\
\hline
\end{tabular}

\section{Summary and Future Perspectives}

The presence of $\mathrm{MB}$ in natural water is harmful to humans and harms microbes and aquatic life due to its toxic nature. Photodegradation is found to be an effective and economical approach for the complete decolourization and mineralization of MB dye into nontoxic species. The effect of different parameters shows that photodegradation of MB increases with increasing irradiation time, photocatalysts dosage, $\mathrm{pH}$ of the medium, oxidants, and decreasing initial dye concentration. The effect of radical scavengers revealed that ${ }^{\bullet} \mathrm{OH}$ is the main species in $\mathrm{MB}$ degradation. The impact of inorganic anions shows that anions may show the negative, positive or dual effect on the photodegradation of $\mathrm{MB}$, which depends on its concentration and the nature of the photocatalyst. The mechanism and 
reactions pathways analysis revealed that $\mathrm{MB}$ dye first converted into different intermediate products and then completely mineralized into $\mathrm{CO}_{2}, \mathrm{H}_{2} \mathrm{O}, \mathrm{NO}_{3}{ }^{-}, \mathrm{SO}_{4}{ }^{2-}$ and $\mathrm{Cl}$.

There are a few dimensions that still require thorough investigations to not only effectively remove the $\mathrm{MB}$ dyes but also increase their practical usage in various applications.

1. The wettability and optical properties of MB suggest its hydrophobic and strong fluorescent nature. Its emission peak is observed at $686 \mathrm{~nm}\left(\lambda_{\mathrm{ex}} 665 \mathrm{~nm}\right)$, and this property can be exploited in multiple advanced applications. Due to these rationalities, MB has recently been used as an extrinsic fluorophore to study the micellization behaviour of drug delivery systems, i.e., bile salts (BS) [289]. The fluorescence response was monitored by fluorescence anisotropy at $686 \mathrm{~nm}$, which indicates the MB-BS (MB-bile salt) association supported by the heat of formation values. This definitive study suggests the future potential of MB dyes as extrinsic fluorescence probes [289]. Moreover, the same property (in combination with various NPs) can be used in future imaging/diagnosis and treatment of tumours and other diagnostic applications [290]. Moreover, these properties can aid with optical sensor fabrication, though limited literature is available on the topic.

2. An important unexplored dimension is to utilize modified $M B$ dye in petroleum applications. The fluorescent nature of these materials could be helpful to probe the oil pockets, map the oil transport pathways and investigate various mechanisms, especially at the dead ends of the rock, where the operational conditions and depth hindered the application of the usual investigative techniques.

3. Another critical aspect, which can be further investigated, is to convert the MB to beneficial and viable products via in situ bioconversion approaches. These investigations will not only remove the $\mathrm{MB}$ from the aqueous medium but also help to generate a variety of lower molecular products.

4. Lastly, the simple adsorption approach for removal of MB dye needs to rediscover by utilizing modern concepts and materials. The ultimate goal should be to achieve greater efficiency at a cheaper cost. In this regard, various naturally available supports, especially the plant bio sorbents, still possess enough potential. Recently, the fava bean peels Vicia faba (FBP), were explored for the removal of methylene blue (MB) dye, a novel ultrasonic-assisted shaking sorption. The comparison with conventional shaking indicates that the MB removal efficiency reached $90 \%$ at $50 \mathrm{mg} / \mathrm{L}$ of the initial dye concentration for the ultrasonic-assisted sorbents in a remarkably shorter time $[58,291]$.

Author Contributions: Conceptualization, I.K. (Idrees Khan) and I.K. (Ibrahim Khan); methodology, K.S. and I.Z.; software, A.A.; validation, A.A.; formal analysis, S.A.; investigation, H.A.; resources, N.Z.; data curation; writing — original draft preparation, S.A. and N.Z.; writing—review and editing, T.S. and L.A.S.; visualization, S.A.; supervision, B.Z.; project administration, B.Z. and T.S.; review and editing, B.Z.; Revision, I.K. (Idrees Khan), I.K. (Ibrahim Khan) and A.H.H. All authors have read and agreed to the published version of the manuscript.

Funding: This research was funded by project nr T190087MIMV and European Commission, MLTK19481R, and by project KIK 15392 and 15401 by European Commission.

Institutional Review Board Statement: Not applicable.

Informed Consent Statement: Not applicable.

Data Availability Statement: Not applicable.

Conflicts of Interest: The authors declare that they have no conflict of interest.

\section{References}

1. Benkhaya, S.; M'rabet, S.; El Harfi, A. A review on classifications, recent synthesis and applications of textile dyes. Inorg. Chem. Commun. 2020, 115, 107891. [CrossRef]

2. Abd-Elhamid, A.I.; Emran, M.; El-Sadek, M.H.; El-Shanshory, A.A.; Soliman, H.M.A.; Akl, M.A.; Rashad, M. Enhanced removal of cationic dye by eco-friendly activated biochar derived from rice straw. Appl. Water Sci. 2020, 10, 45. [CrossRef] 
3. Bouras, H.D.; Isik, Z.; Arikan, E.B.; Yeddou, A.R.; Bouras, N.; Chergui, A.; Favier, L.; Amrane, A.; Dizge, N. Biosorption characteristics of methylene blue dye by two fungal biomasses. Int. J. Environ. Stud. 2020, 78, 365-381. [CrossRef]

4. Tara, N.; Siddiqui, S.I.; Rathi, G.; Chaudhry, S.A.; Inamuddin; Asiri, A.M. Nano-engineered Adsorbent for the Removal of Dyes from Water: A Review. Curr. Anal. Chem. 2019, 16, 14-40. [CrossRef]

5. Khan, I.; Khan, I.; Usman, M.; Imran, M.; Saeed, K. Nanoclay-mediated photocatalytic activity enhancement of copper oxide nanoparticles for enhanced methyl orange photodegradation. J. Mater. Sci. Mater. Electron. 2020, 31, 8971-8985. [CrossRef]

6. Alencar, L.V.T.D.; Passos, L.M.S.; Soares, C.M.F.; Lima, A.S.; Souza, R.L. Efficiency Method for Methylene Blue Recovery Using Aqueous Two-Phase Systems Based on Cholinium-Ionic Liquids. J. Fash. Technol. Text. Eng. 2020, 6, 13-20. [CrossRef]

7. Ahmad, A.; Mohd-Setapar, S.H.; Chuong, C.S.; Khatoon, A.; Wani, W.A.; Kumar, R.; Rafatullah, M. Recent advances in new generation dye removal technologies: Novel search for approaches to reprocess wastewater. RSC Adv. 2015, 5, 30801-30818. [CrossRef]

8. Ahmad, M.; Rehman, W.; Khan, M.M.; Qureshi, M.T.; Gul, A.; Haq, S.; Ullah, R.; Rab, A.; Menaa, F. Phytogenic fabrication of ZnO and gold decorated $\mathrm{ZnO}$ nanoparticles for photocatalytic degradation of Rhodamine B. J. Environ. Chem. Eng. 2021, 9, 104725. [CrossRef]

9. Pandey, S.; Do, J.Y.; Kim, J.; Kang, M. Fast and highly efficient removal of dye from aqueous solution using natural locust bean gum based hydrogels as adsorbent. Int. J. Biol. Macromol. 2020, 143, 60-75. [CrossRef]

10. Fong, W.M.; Affam, A.C.; Chung, W.C. Synthesis of Ag/Fe/CAC for colour and COD removal from methylene blue dye wastewater. Int. J. Environ. Sci. Technol. 2020, 17, 3485-3494. [CrossRef]

11. Derakhshan, Z.; Baghapour, M.A.; Ranjbar, M.; Faramarzian, M. Adsorption of Methylene Blue Dye from Aqueous Solutions by Modified Pumice Stone: Kinetics and Equilibrium Studies. Health Scope 2013, 2, 136-144. [CrossRef]

12. Allouche, F.N.; Yassaa, N. Potential adsorption of methylene blue from aqueous solution using green macroalgae Posidonia oceanica. In Proceedings of the IOP Conference Series: Materials Science and Engineering, International Conference on Functional Materials and Chemical Engineering (ICFMCE 2017), Dubai, UAE, 24-26 November 2017; Volume 323, p. 012006.

13. Han, T.H.; Khan, M.M.; Kalathil, S.; Lee, J.; Cho, M.H. Simultaneous enhancement of methylene blue degradation and power generation in a microbial fuel cell by gold nanoparticles. Ind. Eng. Chem. Res. 2013, 52, 8174-8181. [CrossRef]

14. Rafatullah, M.; Sulaiman, O.; Hashim, R.; Ahmad, A. Adsorption of methylene blue on low-cost adsorbents: A review. J. Hazard. Mater. 2010, 177, 70-80. [CrossRef]

15. Santoso, E.; Ediati, R.; Kusumawati, Y.; Bahruji, H.; Sulistiono, D.O.; Prasetyoko, D. Review on recent advances of carbon based adsorbent for methylene blue removal from waste water. Mater. Today Chem. 2020, 16, 100233. [CrossRef]

16. Mashkoor, F.; Nasar, A. Magsorbents: Potential candidates in wastewater treatment technology-A review on the removal of methylene blue dye. J. Magn. Magn. Mater. 2020, 500, 166408. [CrossRef]

17. Zamel, D.; Khan, A.U. Bacterial immobilization on cellulose acetate based nanofibers for methylene blue removal from wastewater: Mini-review. Inorg. Chem. Commun. 2021, 131, 108766. [CrossRef]

18. Din, M.I.; Khalid, R.; Najeeb, J.; Hussain, Z. Fundamentals and photocatalysis of methylene blue dye using various nanocatalytic assemblies-A critical review. J. Clean. Prod. 2021, 298, 126567. [CrossRef]

19. Sahu, S.; Pahi, S.; Sahu, J.K.; Sahu, U.K.; Patel, R.K. Kendu (Diospyros melanoxylon Roxb) fruit peel activated carbon-an efficient bioadsorbent for methylene blue dye: Equilibrium, kinetic, and thermodynamic study. Environ. Sci. Pollut. Res. 2020, 27, 22579-22592. [CrossRef]

20. Amode, J.O.; Santos, J.H.; Md Alam, Z.; Mirza, A.H.; Mei, C.C. Adsorption of methylene blue from aqueous solution using untreated and treated (Metroxylon spp.) waste adsorbent: Equilibrium and kinetics studies. Int. J. Ind. Chem. 2016, 7, 333-345. [CrossRef]

21. Kuang, Y.; Zhang, X.; Zhou, S. Adsorption of Methylene Blue in Water onto Activated Carbon by Surfactant Modification. Water 2020, 12, 587. [CrossRef]

22. Makeswari, M.; Saraswathi, P. Photo catalytic degradation of methylene blue and methyl orange from aqueous solution using solar light onto chitosan bi-metal oxide composite. SN Appl. Sci. 2020, 2, 336. [CrossRef]

23. Sabar, S.; Abdul Aziz, H.; Yusof, N.H.; Subramaniam, S.; Foo, K.Y.; Wilson, L.D.; Lee, H.K. Preparation of sulfonated chitosan for enhanced adsorption of methylene blue from aqueous solution. React. Funct. Polym. 2020, 151, 104584. [CrossRef]

24. Cheng, J.; Zhan, C.; Wu, J.; Cui, Z.; Si, J.; Wang, Q.; Peng, X.; Turng, L.S. Highly Efficient Removal of Methylene Blue Dye from an Aqueous Solution Using Cellulose Acetate Nanofibrous Membranes Modified by Polydopamine. ACS Omega 2020, 5, 5389-5400. [CrossRef]

25. Wei, X.; Wang, Y.; Feng, Y.; Xie, X.; Li, X.; Yang, S. Different adsorption-degradation behavior of methylene blue and Congo red in nanoceria/H 2 O 2 system under alkaline conditions. Sci. Rep. 2019, 9, 4964. [CrossRef]

26. Anushree, C.; Philip, J. Efficient removal of methylene blue dye using cellulose capped $\mathrm{Fe}_{3} \mathrm{O}_{4}$ nanofluids prepared using oxidation-precipitation method. Colloids Surf. A Physicochem. Eng. Asp. 2019, 567, 193-204. [CrossRef]

27. Albayati, T.M.; Sabri, A.A.; Alazawi, R.A. Separation of Methylene Blue as Pollutant of Water by SBA-15 in a Fixed-Bed Column. Arab. J. Sci. Eng. 2016, 41, 2409-2415. [CrossRef]

28. Saeed, M.; Jamal, M.A.; Haq, A.U.; Ilyas, M.; Younas, M.; Shahzad, M.A. Oxidative Degradation of Methylene Blue in Aqueous Medium Catalyzed by Lab Prepared Nickel Hydroxide. Int. J. Chem. React. Eng. 2016, 14, 45-51. [CrossRef] 
29. Zhang, J.; Zhang, Y.; Lei, Y.; Pan, C. Photocatalytic and degradation mechanisms of anatase TiO ${ }_{2}$ : A HRTEM study. Catal. Sci. Technol. 2011, 1, 273-278. [CrossRef]

30. Saad, M.E.K.; Mnasri, N.; Mhamdi, M.; Chafik, T.; Elaloui, E.; Moussaoui, Y. Removal of methylene blue onto mineral matrices Desalin. Water Treat. 2015, 56, 2773-2780. [CrossRef]

31. Kahlert, H.; Meyer, G.; Albrecht, A. Colour maps of acid-base titrations with colour indicators: How to choose the appropriate indicator and how to estimate the systematic titration errors. ChemTexts 2016, 2, 7. [CrossRef]

32. Pomicpic, J.; Dancel, G.C.; Cabalar, P.J.; Madrid, J. Methylene blue removal by poly(acrylic acid)-grafted pineapple leaf fiber/polyester nonwoven fabric adsorbent and its comparison with removal by gamma or electron beam irradiation. $R a-$ diat. Phys. Chem. 2020, 172, 108737. [CrossRef]

33. Rao, H.; Lu, Z.; Liu, X.; Ge, H.; Zhang, Z.; Zou, P.; He, H.; Wang, Y. Visible light-driven photocatalytic degradation performance for methylene blue with different multi-morphological features of ZnS. RSC Adv. 2016, 6, 46299-46307. [CrossRef]

34. Zhu, L.; Hong, M.; Ho, G.W. Fabrication of wheat grain textured $\mathrm{TiO}_{2} / \mathrm{CuO}$ composite nanofibers for enhanced solar $\mathrm{H} 2$ generation and degradation performance. Nano Energy 2015, 11, 28-37. [CrossRef]

35. Ali, S.; Khan, S.A.; Khan, I.; Yamani, Z.H.; Sohail, M.; Morsy, M.A. Surfactant-free synthesis of ellipsoidal and spherical shaped $\mathrm{TiO}_{2}$ nanoparticles and their comparative photocatalytic studies. J. Environ. Chem. Eng. 2017, 5, 3956-3962. [CrossRef]

36. Barnes, R.J.; Molina, R.; Xu, J.; Dobson, P.J.; Thompson, I.P. Comparison of $\mathrm{TiO}_{2}$ and $\mathrm{ZnO}$ nanoparticles for photocatalytic degradation of methylene blue and the correlated inactivation of gram-positive and gram-negative bacteria. J. Nanopart. Res. 2013, 15, 1432. [CrossRef]

37. Ashraf, M.; Khan, I.; Usman, M.; Khan, A.; Shah, S.S.; Khan, A.Z.; Saeed, K.; Yaseen, M.; Ehsan, M.F.; Nawaz Tahir, M.; et al Hematite and Magnetite Nanostructures for Green and Sustainable Energy Harnessing and Environmental Pollution Control: A Review. Chem. Res. Toxicol. 2020, 33, 1292-1311. [CrossRef]

38. Khan, I.; Khalil, A.; Khanday, F.; Shemsi, A.M.; Qurashi, A.; Siddiqui, K.S. Synthesis, Characterization and Applications of Magnetic Iron Oxide Nanostructures. Arab. J. Sci. Eng. 2018, 43, 43-61. [CrossRef]

39. Khan, I.; Qurashi, A. Sonochemical-Assisted In Situ Electrochemical Synthesis of $\mathrm{Ag} / \alpha-\mathrm{Fe}_{2} \mathrm{O}_{3} / \mathrm{TiO}_{2} \mathrm{Nanoarrays}$ to Harness Energy from Photoelectrochemical Water Splitting. ACS Sustain. Chem. Eng. 2018, 6, 11235-11245. [CrossRef]

40. Sarfraz, N.; Khan, I.; Sarfaraz, N.; Khan, I.; Sarfraz, N.; Khan, I. Plasmonic Gold Nanoparticles (AuNPs): Properties, Synthesis and their Advanced Energy, Environmental and Biomedical Applications. Chem.-Asian J. 2021, 16, 720-742. [CrossRef]

41. Lu, D.; Wang, H.; Zhao, X.; Kondamareddy, K.K.; Ding, J.; Li, C.; Fang, P. Highly efficient visible-light-induced photoactivity of Z-scheme g- $\mathrm{C}_{3} \mathrm{~N}_{4} / \mathrm{Ag} / \mathrm{MoS}_{2}$ ternary photocatalysts for organic pollutant degradation and production of hydrogen. ACS Sustain. Chem. Eng. 2017, 5, 1436-1445. [CrossRef]

42. Ghafoor, S.; Ata, S.; Mahmood, N.; Arshad, S.N. Photosensitization of $\mathrm{TiO}_{2}$ nanofibers by $\mathrm{Ag}_{2} \mathrm{~S}$ with the synergistic effect of excess surface $\mathrm{Ti}^{3}+$ states for enhanced photocatalytic activity under simulated sunlight. Sci. Rep. 2017, 7, 255. [CrossRef]

43. Ashraf, M.; Khan, I.; Baig, N.; Hendi, A.H.; Ehsan, M.F.; Sarfraz, N. A Bifunctional 2D Interlayered $\beta-\mathrm{Cu}_{2} \mathrm{~V}_{2} \mathrm{O}_{7} / \mathrm{Zn}_{2} \mathrm{~V}_{2} \mathrm{O}_{6}(\mathrm{CZVO})$ Heterojunction for Solar-Driven Nonsacrificial Dye Degradation and Water Oxidation. Energy Technol. 2021, 9, 2100034. [CrossRef]

44. Khan, I.; Qurashi, A. Shape Controlled Synthesis of Copper Vanadate Platelet Nanostructures, Their Optical Band Edges, and Solar-Driven Water Splitting Properties. Sci. Rep. 2017, 7, 14370. [CrossRef]

45. Arumugam, M.; Choi, M.Y. Effect of Operational Parameters on the Degradation of Methylene Blue Using Visible Light Active $\mathrm{BiVO}_{4}$ Photocatalyst. Bull. Korean Chem. Soc. 2020, 41, 304-309. [CrossRef]

46. Guo, W.; Chemelewski, W.D.; Mabayoje, O.; Xiao, P.; Zhang, Y.; Mullins, C.B. Synthesis and Characterization of CuV2O6 and $\mathrm{Cu}_{2} \mathrm{~V}_{2} \mathrm{O}_{7}$ : Two Photoanode Candidates for Photoelectrochemical Water Oxidation. J. Phys. Chem. C 2015, 119, $27220-27227$. [CrossRef]

47. Lamdab, U.; Wetchakun, K.; Phanichphant, S.; Kangwansupamonkon, W.; Wetchakun, N. In $\mathrm{VO}_{4}-\mathrm{BiVO}_{4}$ composite films with enhanced visible light performance for photodegradation of methylene blue. Catal. Today 2016, 278, 291-302. [CrossRef]

48. Tyagi, D.; Wang, H.; Huang, W.; Hu, L.; Tang, Y.; Guo, Z.; Ouyang, Z.; Zhang, H. Recent advances in two-dimensionalmaterial-based sensing technology toward health and environmental monitoring applications. Nanoscale 2020, 12, 3535-3559. [CrossRef]

49. Zhang, Y.; Shen, C.; Lu, X.; Mu, X.; Song, P. Effects of defects in $\mathrm{g}^{-} \mathrm{C}_{3} \mathrm{~N}_{4}$ on excited-state charge distribution and transfer: Potential for improved photocatalysis. Spectrochim. Acta—Part A Mol. Biomol. Spectrosc. 2020, 227, 117687. [CrossRef]

50. Simon, Y.D.T.; Hadis, B.; Estella, T.N.; Arabamiri, M.; Serges, D.; Arnaud, K.T.; Samuel, L.; Minoo, T.; Michael, S.; Reinhard, S. Urea and green tea like precursors for the preparation of g-C3N4 based carbon nanomaterials (CNMs) composites as photocatalysts for photodegradation of pollutants under UV light irradiation. J. Photochem. Photobiol. A Chem. 2020, 398, 112596. [CrossRef]

51. Ai, B.; Duan, X.; Sun, H.; Qiu, X.; Wang, S. Metal-free graphene-carbon nitride hybrids for photodegradation of organic pollutants in water. Catal. Today 2015, 258, 668-675. [CrossRef]

52. de Oliveira Guidolin, T.; Possolli, N.M.; Polla, M.B.; Wermuth, T.B.; Franco de Oliveira, T.; Eller, S.; Klegues Montedo, O.R.; Arcaro, S.; Cechinel, M.A.P. Photocatalytic pathway on the degradation of methylene blue from aqueous solutions using magnetite nanoparticles. J. Clean. Prod. 2021, 318, 128556. [CrossRef]

53. Chen, H.; Chen, N.; Gao, Y.; Feng, C. Photocatalytic degradation of methylene blue by magnetically recoverable Fe3O4/Ag6Si2O7 under simulated visible light. Powder Technol. 2018, 326, 247-254. [CrossRef] 
54. Chakraborty, B.; Ray, L.; Basu, S. Biochemical degradation of Methylene Blue using a continuous reactor packed with solid waste by E. coli and Bacillus subtilis isolated from wetland soil. Desalin. Water Treat. 2016, 57, 14077-14082. [CrossRef]

55. Wijaya, R.; Andersan, G.; Permatasari Santoso, S.; Irawaty, W. Green Reduction of Graphene Oxide using Kaffir Lime Peel Extract (Citrus hystrix) and Its Application as Adsorbent for Methylene Blue. Sci. Rep. 2020, 10, 667. [CrossRef]

56. Mahmoud, M.S.; Farah, J.Y.; Farrag, T.E. Enhanced removal of Methylene Blue by electrocoagulation using iron electrodes. Egypt. J. Pet. 2013, 22, 211-216. [CrossRef]

57. Jia, P.; Tan, H.; Liu, K.; Gao, W. Removal of Methylene Blue from Aqueous Solution by Bone Char. Appl. Sci. 2018, 8, 1903. [CrossRef]

58. Bayomie, O.S.; Kandeel, H.; Shoeib, T.; Yang, H.; Youssef, N.; El-Sayed, M.M.H. Novel approach for effective removal of methylene blue dye from water using fava bean peel waste. Sci. Rep. 2020, 10, 7824. [CrossRef]

59. Sousa, H.R.; Silva, L.S.; Sousa, P.A.A.; Sousa, R.R.M.; Fonseca, M.G.; Osajima, J.A.; Silva-Filho, E.C. Evaluation of methylene blue removal by plasma activated palygorskites. J. Mater. Res. Technol. 2019, 8, 5432-5442. [CrossRef]

60. Salimi, A.; Roosta, A. Experimental solubility and thermodynamic aspects of methylene blue in different solvents. Thermochim. Acta 2019, 675, 134-139. [CrossRef]

61. Pham, V.L.; Kim, D.-G.; Ko, S.-O. Mechanisms of Methylene Blue Degradation by Nano-Sized $\beta-\mathrm{MnO}_{2}$ Particles. KSCE J. Civ. Eng. 2020, 24, 1976-3808. [CrossRef]

62. Potential Biosorbent Derived from Calligonum Polygonoides for Removal of Methylene Blue Dye from Aqueous Solution. Available online: https:/ / www.hindawi.com/journals/tswj/2015/562693/ (accessed on 1 July 2020).

63. Kazemi, F.; Mohamadnia, Z.; Kaboudin, B.; Karimi, Z. Photodegradation of methylene blue with a titanium dioxide/polyacrylamide photocatalyst under sunlight. J. Appl. Polym. Sci. 2016, 133, 43386. [CrossRef]

64. Lu, Q.; Zhang, Y.; Liu, S. Graphene quantum dots enhanced photocatalytic activity of zinc porphyrin toward the degradation of methylene blue under visible-light irradiation. J. Mater. Chem. A 2015, 3, 8552-8558. [CrossRef]

65. Huang, S.; Li, H.; Wang, Y.; Liu, X.; Li, H.; Zhan, Z.; Jia, L.; Chen, L. Monitoring of oxygen using colorimetric indicator based on graphene $/ \mathrm{TiO}_{2}$ composite with first-order kinetics of methylene blue for modified atmosphere packaging. Packag. Technol. Sci. 2018, 31, 575-584. [CrossRef]

66. Yang, C.; Dong, W.; Cui, G.; Zhao, Y.; Shi, X.; Xia, X.; Tang, B.; Wang, W. Highly efficient photocatalytic degradation of methylene blue by P2ABSA-modified $\mathrm{TiO}_{2}$ nanocomposite due to the photosensitization synergetic effect of $\mathrm{TiO}_{2}$ and P2ABSA. RSC Adv. 2017, 7, 23699-23708. [CrossRef]

67. Mondal, S.; De Anda Reyes, M.E.; Pal, U. Plasmon induced enhanced photocatalytic activity of gold loaded hydroxyapatite nanoparticles for methylene blue degradation under visible light. RSC Adv. 2017, 7, 8633-8645. [CrossRef]

68. Lin, J.; Luo, Z.; Liu, J.; Li, P. Photocatalytic degradation of methylene blue in aqueous solution by using $\mathrm{ZnO}^{-S n O} \mathrm{O}_{2}$ nanocomposites. Mater. Sci. Semicond. Process. 2018, 87, 24-31. [CrossRef]

69. Xia, Y.; Yao, Q.; Zhang, W.; Zhang, Y.; Zhao, M. Comparative adsorption of methylene blue by magnetic baker's yeast and EDTAD-modified magnetic baker's yeast: Equilibrium and kinetic study. Arab. J. Chem. 2019, 12, 2448-2456. [CrossRef]

70. Xu, A.; Li, X.; Ye, S.; Yin, G.; Zeng, Q. Catalyzed oxidative degradation of methylene blue by in situ generated cobalt (II)bicarbonate complexes with hydrogen peroxide. Appl. Catal. B Environ. 2011, 102, 37-43. [CrossRef]

71. Teng, X.; Li, J.; Wang, Z.; Wei, Z.; Chen, C.; Du, K.; Zhao, C.; Yang, G.; Li, Y. Performance and mechanism of methylene blue degradation by an electrochemical process. RSC Adv. 2020, 10, 24712-24720. [CrossRef]

72. Dao, H.M.; Whang, C.H.; Shankar, V.K.; Wang, Y.H.; Khan, I.A.; Walker, L.A.; Husain, I.; Khan, S.I.; Murthy, S.N.; Jo, S. Methylene blue as a far-red light-mediated photocleavable multifunctional ligand. Chem. Commun. 2020, 56, 1673-1676. [CrossRef]

73. Hou, C.; Hu, B.; Zhu, J. Photocatalytic Degradation of Methylene Blue over $\mathrm{TiO}_{2}$ Pretreated with Varying Concentrations of $\mathrm{NaOH}$. Catalysts 2018, 8, 575. [CrossRef]

74. Lu, G.; Nagbanshi, M.; Goldau, N.; Mendes Jorge, M.; Meissner, P.; Jahn, A.; Mockenhaupt, F.P.; Müller, O. Efficacy and safety of methylene blue in the treatment of malaria: A systematic review. BMC Med. 2018, 16, 59. [CrossRef] [PubMed]

75. Schirmer, R.H.; Coulibaly, B.; Stich, A.; Scheiwein, M.; Merkle, H.; Eubel, J.; Becker, K.; Becher, H.; Müller, O.; Zich, T.; et al. Methylene blue as an antimalarial agent. Redox Rep. 2003, 8, 272-275. [CrossRef]

76. Uddin, M.K.; Nasar, A. Decolorization of Basic Dyes Solution by Utilizing Fruit Seed Powder. KSCE J. Civ. Eng. 2020, 24, 345-355. [CrossRef]

77. Saha, B.; Chowdhury, S.; Sanyal, D.; Chattopadhyay, K.; Suresh Kumar, G. Comparative Study of Toluidine Blue O and Methylene Blue Binding to Lysozyme and Their Inhibitory Effects on Protein Aggregation. ACS Omega 2018, 3, 2588-2601. [CrossRef] [PubMed]

78. Oz, M.; Lorke, D.E.; Hasan, M.; Petroianu, G.A. Cellular and molecular actions of Methylene Blue in the nervous system. Med. Res. Rev. 2011, 31, 93-117. [CrossRef]

79. Marimuthu, M.; Praveen Kumar, B.; Mariya Salomi, L.; Veerapandian, M.; Balamurugan, K. Methylene Blue-Fortified Molybdenum Trioxide Nanoparticles: Harnessing Radical Scavenging Property. ACS Appl. Mater. Interfaces 2018, 10, 43429-43438. [CrossRef]

80. Lo, J.C.Y.; Darracq, M.A.; Clark, R.F. A review of methylene blue treatment for cardiovascular collapse. J. Emerg. Med. 2014, 46, 670-679. [CrossRef] [PubMed] 
81. Nedu, M.E.; Tertis, M.; Cristea, C.; Georgescu, A.V. Comparative study regarding the properties of methylene blue and proflavine and their optimal concentrations for in vitro and in vivo applications. Diagnostics 2020, 10, 223. [CrossRef] [PubMed]

82. Koyuncu, H.; Kul, A.R. Removal of methylene blue dye from aqueous solution by nonliving lichen (Pseudevernia furfuracea (L.) Zopf.), as a novel biosorbent. Appl. Water Sci. 2020, 10, 72. [CrossRef]

83. Mijinyawa, A.H.; Durga, G.; Mishra, A. A sustainable process for adsorptive removal of methylene blue onto a food grade mucilage: Kinetics, thermodynamics, and equilibrium evaluation. Int. J. Phytoremediat. 2019, 21, 1122-1129. [CrossRef]

84. Parakala, S.; Moulik, S.; Sridhar, S. Effective separation of methylene blue dye from aqueous solutions by integration of micellar enhanced ultrafiltration with vacuum membrane distillation. Chem. Eng. J. 2019, 375, 122015. [CrossRef]

85. Balarak, D.; Bazzi, M.; Shehu, Z.; Chandrika, K. Application of Surfactant-Modified Bentonite for Methylene Blue Adsorption from Aqueous Solution. Orient. J. Chem. 2020, 36, 293-299. [CrossRef]

86. Arias Arias, F.; Guevara, M.; Tene, T.; Angamarca, P.; Molina, R.; Valarezo, A.; Salguero, O.; Vacacela Gomez, C.; Arias, M.; Caputi, L.S. The Adsorption of Methylene Blue on Eco-Friendly Reduced Graphene Oxide. Nanomaterials 2020, 10, 681. [CrossRef] [PubMed]

87. Siddeeg, S.M.; Tahoon, M.A.; Mnif, W.; Ben Rebah, F. Iron Oxide/Chitosan Magnetic Nanocomposite Immobilized Manganese Peroxidase for Decolorization of Textile Wastewater. Processes 2019, 8, 5. [CrossRef]

88. Manimohan, M.; Pugalmani, S.; Ravichandran, K.; Sithique, M.A. Synthesis and characterisation of novel Cu(II)-anchored biopolymer complexes as reusable materials for the photocatalytic degradation of methylene blue. RSC Adv. 2020, 10, 18259-18279. [CrossRef]

89. Giannakopoulou, P.P.; Petrounias, P.; Rogkala, A.; Lampropoulou, P.; Gianni, E.; Papoulis, D.; Koutsovitis, P.; Tsikouras, B.; Hatzipanagiotou, K. Does the Methylene Blue Test Give Equally Satisfactory Results in All Studied Igneous Rocks Relative to the Identification of Swelling Clay Minerals? Minerals 2020, 10, 283. [CrossRef]

90. Zaghbani, N.; Hafiane, A.; Dhahbi, M. Separation of methylene blue from aqueous solution by micellar enhanced ultrafiltration. Sep. Purif. Technol. 2007, 55, 117-124. [CrossRef]

91. De Crozals, G.; Farre, C.; Sigaud, M.; Fortgang, P.; Sanglar, C.; Chaix, C. Methylene blue phosphoramidite for DNA labelling Chem. Commun. 2015, 51, 4458-4461. [CrossRef]

92. Dante, R.C.; Trakulmututa, J.; Meejoo-Smith, S.; Martín-Ramos, P.; Chamorro-Posada, P.; Rutto, D.; Sánchez-Arévalo, F.M. Methylene blue-carbon nitride system as a reusable air-sensor. Mater. Chem. Phys. 2019, 231, 351-356. [CrossRef]

93. A Novel of Buton Asphalt and Methylene Blue as Dye-Sensitized Solar Cell using $\mathrm{TiO}_{2} / \mathrm{Ti}$ Nanotubes Electrode-IOPscience. Available online: https:/ /iopscience.iop.org/article/10.1088/1757-899X/267/1/012035 (accessed on 14 May 2020).

94. Reda, S.M.; El-Sherbieny, S.A. Dye-sensitized nanocrystalline CdS and ZnS solar cells with different organic dyes. J. Mater. Res. 2010, 25, 522-528. [CrossRef]

95. Zhang, Y.; An, Y.; Wu, L.; Chen, H.; Li, Z.; Dou, H.; Murugadoss, V.; Fan, J.; Zhang, X.; Mai, X.; et al. Metal-free energy storage systems: Combining batteries with capacitors based on a methylene blue functionalized graphene cathode. J. Mater. Chem. A 2019, 7, 19668-19675. [CrossRef]

96. López-Carballo, G.; Muriel-Galet, V.; Hernández-Muñoz, P.; Gavara, R. Gavara Chromatic Sensor to Determine Oxygen Presence for Applications in Intelligent Packaging. Sensors 2019, 19, 4684. [CrossRef]

97. Hoffmann, A.A.; Dias, S.L.P.; Rodrigues, J.R.; Pavan, F.A.; Benvenutti, E.V.; Lima, E.C. Methylene blue immobilized on cellulose acetate with titanium dioxide: An application as sensor for ascorbic acid. J. Braz. Chem. Soc. 2008, 19, 943-949. [CrossRef]

98. Rahimnejad, M.; Najafpour, G.D.; Ghoreyshi, A.A.; Shakeri, M.; Zare, H. Methylene blue as electron promoters in microbial fuel cell. Int. J. Hydrogen Energy 2011, 36, 13335-13341. [CrossRef]

99. Pang, Y.; Tong, Z.H.; Tang, L.; Liu, Y.N.; Luo, K. Effect of humic acid on the degradation of methylene blue by peroxymonosulfate. Open Chem. 2018, 16, 401-406. [CrossRef]

100. Sun, L.; Hu, D.; Zhang, Z.; Deng, X. Oxidative degradation of methylene blue via PDS-based advanced oxidation process using natural pyrite. Int. J. Environ. Res. Public Health 2019, 16, 4773. [CrossRef] [PubMed]

101. Contreras, M.; Grande-Tovar, C.D.; Vallejo, W.; Chaves-López, C. Bio-Removal of Methylene Blue from Aqueous Solution by Galactomyces geotrichum KL20A. Water 2019, 11, 282. [CrossRef]

102. Abdelrahman, E.A.; Hegazey, R.M.; El-Azabawy, R.E. Efficient removal of methylene blue dye from aqueous media using Fe/Si, $\mathrm{Cr} / \mathrm{Si}, \mathrm{Ni} / \mathrm{Si}$, and Zn/Si amorphous novel adsorbents. J. Mater. Res. Technol. 2019, 8, 5301-5313. [CrossRef]

103. Jawad, A.H.; Abdulhameed, A.S.; Mastuli, M.S. Acid-factionalized biomass material for methylene blue dye removal: A comprehensive adsorption and mechanism study. J. Taibah Univ. Sci. 2020, 14, 305-313. [CrossRef]

104. Cusioli, L.F.; Quesada, H.B.; Baptista, A.T.A.; Gomes, R.G.; Bergamasco, R. Soybean hulls as a low-cost biosorbent for removal of methylene blue contaminant. Environ. Prog. Sustain. Energy 2020, 39, e13328. [CrossRef]

105. Staron, P.; Chwastowski, J.; Banach, M. Sorption behavior of methylene blue from aqueous solution by raphia fibers. Int. J. Environ. Sci. Technol. 2019, 16, 8449-8460. [CrossRef]

106. Lebron, Y.A.R.; Moreira, V.R.; de Souza Santos, L.V. Biosorption of methylene blue and eriochrome black T onto the brown macroalgae Fucus vesiculosus: Equilibrium, kinetics, thermodynamics and optimization. Environ. Technol. 2019, 42, $279-297$. [CrossRef]

107. Mabel, M.M.; Sundararaman, T.R.; Parthasarathy, N.; Rajkumar, J. Chitin Beads from Peneaus sp. Shells asa Biosorbent for Methylene Blue Dye Removal. Pol. J. Environ. Stud. 2019, 28, 2253-2259. [CrossRef] 
108. Wang, Y.; Peng, Q.; Akhtar, N.; Chen, X.; Huang, Y. Microporous carbon material from fish waste for removal of methylene blue from wastewater. Water Sci. Technol. 2020, 86, 1180-1190. [CrossRef] [PubMed]

109. Bharti, V.; Vikrant, K.; Goswami, M.; Tiwari, H.; Sonwani, R.K.; Lee, J.; Tsang, D.C.W.; Kim, K.H.; Saeed, M.; Kumar, S.; et al. Biodegradation of methylene blue dye in a batch and continuous mode using biochar as packing media. Environ. Res. 2019, 171, 356-364. [CrossRef]

110. Shakoor, S.; Nasar, A. Adsorptive treatment of hazardous methylene blue dye from artificially contaminated water using cucumis sativus peel waste as a low-cost adsorbent. Groundw. Sustain. Dev. 2017, 5, 152-159. [CrossRef]

111. Ebi Ebi, O.; Falilat Taiwo, A.; Tunde Folorunsho, A. Kinetic Modelling of the Biosorption of Methylene Blue onto Wild Melon (Lagenariasphaerica). Am. J. Chem. Eng. 2018, 6, 126-134. [CrossRef]

112. Zhou, S.; Du, Z.; Li, X.; Zhang, Y.; He, Y.; Zhang, Y. Degradation of methylene blue by natural manganese oxides: Kinetics and transformation products. R. Soc. Open Sci. 2019, 6, 190351. [CrossRef]

113. Lawagon, C.P.; Amon, R.E.C. Magnetic rice husk ash "cleanser" as efficient methylene blue adsorbent. Environ. Eng. Res. 2019, 25, 685-692. [CrossRef]

114. Ahmad Zaini, M.A.; Sudi, R.M. Valorization of human hair as methylene blue dye adsorbents. Green Process. Synth. 2018, 7, 344-352. [CrossRef]

115. Kosswattaarachchi, A.M.; Cook, T.R. Repurposing the Industrial Dye Methylene Blue as an Active Component for Redox Flow Batteries. ChemElectroChem 2018, 5, 3437-3442. [CrossRef]

116. Zamel, D.; Hassanin, A.H.; Ellethy, R.; Singer, G.; Abdelmoneim, A. Novel Bacteria-Immobilized Cellulose Acetate/Poly(ethylene oxide) Nanofibrous Membrane for Wastewater Treatment. Sci. Rep. 2019, 9, 18994. [CrossRef]

117. Thabede, P.M.; Shooto, N.D.; Naidoo, E.B. Removal of methylene blue dye and lead ions from aqueous solution using activated carbon from black cumin seeds. S. Afr. J. Chem. Eng. 2020, 33, 39-50. [CrossRef]

118. Wang, Z.; Gao, M.; Li, X.; Ning, J.; Zhou, Z.; Li, G. Efficient adsorption of methylene blue from aqueous solution by graphene oxide modified persimmon tannins. Mater. Sci. Eng. C 2020, 108, 110196. [CrossRef] [PubMed]

119. Andrade Siqueira, T.C.; Zanette da Silva, I.; Rubio, A.J.; Bergamasco, R.; Gasparotto, F.; Aparecida de Souza Paccola, E.; Ueda Yamaguchi, N. Sugarcane Bagasse as an Efficient Biosorbent for Methylene Blue Removal: Kinetics, Isotherms and Thermodynamics. Int. J. Environ. Res. Public Health 2020, 17, 526. [CrossRef] [PubMed]

120. Regunton, P.C.V.; Sumalapao, D.E.P.; Villarante, N.R. Biosorption of methylene blue from aqueous solution by coconut (Cocos nucifera) shell-derived activated carbon-chitosan composite. Orient. J. Chem. 2018, 34, 115-124. [CrossRef]

121. Gopalakrishnan, A.; Singh, S.P.; Badhulika, S. Reusable, few-layered-MoS ${ }_{2}$ nanosheets/graphene hybrid on cellulose paper for superior adsorption of methylene blue dye. New J. Chem. 2020, 44, 5489-5500. [CrossRef]

122. Hameed, A.M. Synthesis of Si/Cu Amorphous Adsorbent for Efficient Removal of Methylene Blue Dye from Aqueous Media. J. Inorg. Organomet. Polym. Mater. 2020, 30, 2881-2889. [CrossRef]

123. Li, H.; Liu, L.; Cui, J.; Cui, J.; Wang, F.; Zhang, F. High-efficiency adsorption and regeneration of methylene blue and aniline onto activated carbon from waste edible fungus residue and its possible mechanism. RSC Adv. 2020, 10, 14262-14273. [CrossRef]

124. Imron, M.F.; Kurniawan, S.B.; Soegianto, A.; Wahyudianto, F.E. Phytoremediation of methylene blue using duckweed (Lemna minor). Heliyon 2019, 5, e02206. [CrossRef] [PubMed]

125. Tan, K.A.; Morad, N.; Ooi, J.Q. Phytoremediation of Methylene Blue and Methyl Orange Using Eichhornia crassipes. Int. J. Environ. Sci. Dev. 2016, 7, 724-728. [CrossRef]

126. Lau, Y.Y.; Wong, Y.S.; Teng, T.T.; Morad, N.; Rafatullah, M.; Ong, S.A. Degradation of cationic and anionic dyes in coagulationflocculation process using bi-functionalized silica hybrid with aluminum-ferric as auxiliary agent. RSC Adv. 2015, 5, 34206-34215. [CrossRef]

127. Liu, J.; Li, P.; Xiao, H.; Zhang, Y.; Shi, X.; Lü, X.; Chen, X. Understanding flocculation mechanism of graphene oxide for organic dyes from water: Experimental and molecular dynamics simulation. AIP Adv. 2015, 5, 117151. [CrossRef]

128. Tir, M.; Moulai-Mostefa, N.; Nedjhioui, M. Optimizing decolorization of methylene blue dye by electrocoagulation using Taguchi approach. Desalin. Water Treat. 2015, 55, 2705-2710. [CrossRef]

129. Banat, F.; Al-Asheh, S.; Qtaishat, M. Treatment of waters colored with methylene blue dye by vacuum membrane distillation. Desalination 2005, 174, 87-96. [CrossRef]

130. El-Ashtoukhy, E.S.Z.; Fouad, Y.O. Liquid-liquid extraction of methylene blue dye from aqueous solutions using sodium dodecylbenzenesulfonate as an extractant. Alex. Eng. J. 2015, 54, 77-81. [CrossRef]

131. Zheng, L.; Su, Y.; Wang, L.; Jiang, Z. Adsorption and recovery of methylene blue from aqueous solution through ultrafiltration technique. Sep. Purif. Technol. 2009, 68, 244-249. [CrossRef]

132. Khosa, M.A.; Shah, S.S.; Nazar, M.F. Application of micellar enhanced ultrafiltration for the removal of methylene blue from aqueous solution. J. Dispers. Sci. Technol. 2011, 32, 260-264. [CrossRef]

133. Kim, S.; Yu, M.; Yoon, Y. Fouling and Retention Mechanisms of Selected Cationic and Anionic Dyes in a Ti3C2Tx MXeneUltrafiltration Hybrid System. ACS Appl. Mater. Interfaces 2020, 12, 16557-16565. [CrossRef]

134. Kong, G.; Pang, J.; Tang, Y.; Fan, L.; Sun, H.; Wang, R.; Feng, S.; Feng, Y.; Fan, W.; Kang, W.; et al. Efficient dye nanofiltration of a graphene oxide membrane: Via combination with a covalent organic framework by hot pressing. J. Mater. Chem. A 2019, 7, 24301-24310. [CrossRef] 
135. Cheng, S.; Oatley, D.L.; Williams, P.M.; Wright, C.J. Characterisation and application of a novel positively charged nanofiltration membrane for the treatment of textile industry wastewaters. Water Res. 2012, 46, 33-42. [CrossRef] [PubMed]

136. Zhong, F.; Wang, P.; He, Y.; Chen, C.; Li, H.; Yu, H.; Chen, J. Preparation of stable and superior flux GO/LDH/PDA-based nanofiltration membranes through electrostatic self-assembly for dye purification. Polym. Adv. Technol. 2019, 30, $1644-1655$. [CrossRef]

137. García, M.C.; Mora, M.; Esquivel, D.; Foster, J.E.; Rodero, A.; Jiménez-Sanchidrián, C.; Romero-Salguero, F.J. Microwave atmospheric pressure plasma jets for wastewater treatment: Degradation of methylene blue as a model dye. Chemosphere 2017, 180, 239-246. [CrossRef]

138. Eslami, H.; Sedighi Khavidak, S.; Salehi, F.; Khosravi, R.; Fallahzadeh, R.A.; Peirovi, R.; Sadeghi, S. Biodegradation of methylene blue from aqueous solution by bacteria isolated from contaminated soil. J. Adv. Environ. Health Res. 2017, 5, 10-15. [CrossRef]

139. Kilany, M. Isolation, screening and molecular identification of novel bacterial strain removing methylene blue from water solutions. Appl. Water Sci. 2017, 7, 4091-4098. [CrossRef]

140. Van Der Maas, A.S.; Da Silva, N.J.R.; Da Costa, A.S.V.; Barros, A.R.; Bomfeti, C.A. The degradation of methylene blue dye by the strains of pleurotus sp. With potential applications in bioremediation processes. Rev. Ambient. Agua 2018, 13, e2247. [CrossRef]

141. Naresh Yadav, D.; Anand Kishore, K.; Saroj, D. A Study on removal of Methylene Blue dye by photo catalysis integrated with nanofiltration using statistical and experimental approaches. Environ. Technol. 2020, 42, 2968-2981. [CrossRef]

142. Nguyet, P.N.; Watari, T.; Hirakata, Y.; Hatamoto, M.; Yamaguchi, T. Adsorption and biodegradation removal of methylene blue in a down-flow hanging filter reactor incorporating natural adsorbent. Environ. Technol. 2019, 42, 410-418. [CrossRef]

143. Lee, H.; Park, S.H.; Kim, B.H.; Kim, S.J.; Kim, S.C.; Seo, S.G.; Jung, S.C. Contribution of dissolved oxygen to methylene blue decomposition by hybrid advanced oxidation processes system. Int. J. Photoenergy 2012, 2012, 305989. [CrossRef]

144. Sun, Y.; Cheng, S.; Lin, Z.; Yang, J.; Li, C.; Gu, R. Combination of plasma oxidation process with microbial fuel cell for mineralizing methylene blue with high energy efficiency. J. Hazard. Mater. 2020, 384, 121307. [CrossRef]

145. Liu, Q.-X.; Zhou, Y.-R.; Wang, M.; Zhang, Q.; Ji, T.; Chen, T.-Y.; Yu, D.-C. Adsorption of methylene blue from aqueous solution onto viscose-based activated carbon fiber felts: Kinetics and equilibrium studies. Adsorpt. Sci. Technol. 2019, 37, 312-332. [CrossRef]

146. Liu, L.; He, D.; Pan, F.; Huang, R.; Lin, H.; Zhang, X. Comparative study on treatment of methylene blue dye wastewater by different internal electrolysis systems and COD removal kinetics, thermodynamics and mechanism. Chemosphere 2020, $238,124671$. [CrossRef] [PubMed]

147. Crini, G.; Lichtfouse, E. Advantages and disadvantages of techniques used for wastewater treatment. Environ. Chem. Lett. 2019, 17, 145-155. [CrossRef]

148. Photocatalysts in Advanced Oxidation Processes for Wastewater Treatment; John Wiley \& Sons: Hoboken, NJ, USA, 2020. [CrossRef]

149. Khan, I.; Saeed, K.; Ali, N.; Khan, I.; Zhang, B.; Sadiq, M. Heterogeneous photodegradation of industrial dyes: An insight to different mechanisms and rate affecting parameters. J. Environ. Chem. Eng. 2020, 8, 104364. [CrossRef]

150. Zhang, L.C.; Jia, Z.; Lyu, F.; Liang, S.X.; Lu, J. A review of catalytic performance of metallic glasses in wastewater treatment: Recent progress and prospects. Prog. Mater. Sci. 2019, 105, 100576. [CrossRef]

151. Zhang, S.; Wang, D.; Zhang, S.; Zhang, X.; Fan, P. Ozonation and Carbon-assisted Ozonation of Methylene Blue as Model Compound: Effect of Solution pH. Procedia Environ. Sci. 2013, 18, 493-502. [CrossRef]

152. Athikoh, N.; Yulianto, E.; Wibowo Kinandana, A.; Sasmita, E.; Husein Sanjani, A.; Wahyu Mustika, R.; Putra Pratama, A.; Farida Amalia, N.; Gunawan, G.; Nur, M. Reduction of Methylene Blue by Using Direct Continuous Ozone. J. Environ. Earth Sci. 2020, 10, 46-56. [CrossRef]

153. Mohammed, H.A.; Khaleefa, S.A.; Basheer, M.I. Photolysis of Methylene Blue Dye Using an Advanced Oxidation Process (Ultraviolet Light and Hydrogen Peroxide). J. Eng. Sustain. Dev. 2021, 25, 59-67. [CrossRef]

154. Jawad, N.H.; Najim, S.T. Removal of Methylene Blue by Direct Electrochemical Oxidation Method Using a Graphite Anode. IOP Conf. Ser. Mater. Sci. Eng. 2018, 454, 012023. [CrossRef]

155. Kim, J.; Yeom, C.; Kim, Y. Electrochemical degradation of organic dyes with a porous gold electrode. Korean J. Chem. Eng. 2016, 33, 1855-1859. [CrossRef]

156. Guergueb, M.; Nasri, S.; Brahmi, J.; Loiseau, F.; Molton, F.; Roisnel, T.; Guerineau, V.; Turowska-Tyrk, I.; Aouadi, K.; Nasri, H. Effect of the coordination of $\pi$-acceptor 4-cyanopyridine ligand on the structural and electronic properties of: Meso-tetra(para-methoxy) and meso-tetra(para-chlorophenyl) porphyrin cobalt(ii) coordination compounds. Application in the catalytic degradation of methylene blue dye. RSC Adv. 2020, 10, 6900-6918. [CrossRef]

157. Choquehuanca, A.; Ruiz-Montoya, J.G.; Gómez, A.L.R.-T. Discoloration of methylene blue at neutral pH by heterogeneous photo-Fenton-like reactions using crystalline and amorphous iron oxides. Open Chem. 2021, 19, 1009-1020. [CrossRef]

158. Ahmed, Y.; Yaakob, Z.; Akhtar, P. Degradation and mineralization of methylene blue using a heterogeneous photo-Fenton catalyst under visible and solar light irradiation. Catal. Sci. Technol. 2016, 6, 1222-1232. [CrossRef]

159. Dzinun, H.; Ichikawa, Y.; Honda, M.; Zhang, Q. Efficient Immobilised $\mathrm{TiO}_{2}$ in Polyvinylidene fluoride (PVDF) Membrane for Photocatalytic Degradation of Methylene Blue Graphical abstract Keywords. J. Membr. Sci. Res. 2020, 6, 188-195. [CrossRef]

160. Photocatalytic Degradation of Methylene Blue under Visible Light by Dye Sensitized Titania-IOPscience. Available online: https:/ /iopscience.iop.org/article/10.1088/2053-1591/ab6409 (accessed on 9 May 2020). 
161. Krishnan, S.; Rawindran, H.; Sinnathambi, C.M.; Lim, J.W. Comparison of various advanced oxidation processes used in remediation of industrial wastewater laden with recalcitrant pollutants. IOP Conf. Ser. Mater. Sci. Eng. 2017, 206, 012089. [CrossRef]

162. Anglada, Á.; Urtiaga, A.; Ortiz, I. Contributions of electrochemical oxidation to waste-water treatment: Fundamentals and review of applications. J. Chem. Technol. Biotechnol. 2009, 84, 1747-1755. [CrossRef]

163. Balakumara, R.; Sathya, K.; Saravanathamizhan, R. Decolorization of Methylene Blue Dye Using Sonocatalytic Followed by Photocatalytic Process. Water Conserv. Sci. Eng. 2016, 1, 161-166. [CrossRef]

164. Sandoval, A.; Hernández-Ventura, C.; Klimova, T.E. Titanate nanotubes for removal of methylene blue dye by combined adsorption and photocatalysis. Fuel 2017, 198, 22-30. [CrossRef]

165. Xiong, J.; Guo, S.; Zhao, T.; Liang, Y.; Liang, J.; Wang, S.; Zhu, H.; Zhang, L.; Zhao, J.R.; Chen, G. Degradation of methylene blue by intimate coupling photocatalysis and biodegradation with bagasse cellulose composite carrier. Cellulose 2020, 27, 3391-3404. [CrossRef]

166. Chandra, R.; Nath, M. Controlled synthesis of AgNPs@ZIF-8 composite: Efficient heterogeneous photocatalyst for degradation of methylene blue and congo red. J. Water Process Eng. 2020, 36, 101266. [CrossRef]

167. Khaing, K.K.; Yin, D.; Ouyang, Y.; Xiao, S.; Liu, B.; Deng, L.; Li, L.; Guo, X.; Wang, J.; Liu, J.; et al. Fabrication of 2D-2D Heterojunction Catalyst with Covalent Organic Framework (COF) and $\mathrm{MoS}_{2}$ for Highly Efficient Photocatalytic Degradation of Organic Pollutants. Inorg. Chem. 2020, 59, 6942-6952. [CrossRef] [PubMed]

168. Madkour, M.; Allam, O.G.; Abdel Nazeer, A.; Amin, M.O.; Al-Hetlani, E. CeO2-based nanoheterostructures with p-n and n-n heterojunction arrangements for enhancing the solar-driven photodegradation of rhodamine 6G dye. J. Mater. Sci. Mater. Electron. 2019, 30, 10857-10866. [CrossRef]

169. Muhd Julkapli, N.; Bagheri, S.; Bee Abd Hamid, S. Recent advances in heterogeneous photocatalytic decolorization of synthetic dyes. Sci. World J. 2014, 2014, 692307. [CrossRef] [PubMed]

170. Shaban, M.; Elwahab, F.A.; Ghitas, A.E.; El Zayat, M.Y. Efficient and recyclable photocatalytic degradation of methylene blue dye in aqueous solutions using nanostructured Cd1-xCoxS films of different doping levels. J. Sol-Gel Sci. Technol. 2020, 95, 276-288. [CrossRef]

171. Saeed, K.; Khan, I. Efficient photodegradation of neutral red chloride dye in aqueous medium using graphene/cobalt-manganese oxides nanocomposite. Turk. J. Chem. 2017, 41, 391-398. [CrossRef]

172. Khan, I.; Sadiq, M.; Khan, I.; Saeed, K. Manganese dioxide nanoparticles/activated carbon composite as efficient UV and visible-light photocatalyst. Environ. Sci. Pollut. Res. 2019, 26, 5140-5154. [CrossRef]

173. Saeed, K.; Khan, I.; Gul, T.; Sadiq, M. Efficient photodegradation of methyl violet dye using $\mathrm{TiO}_{2} / \mathrm{Pt}$ and TiO $2 / \mathrm{Pd}$ photocatalysts. Appl. Water Sci. 2017, 7, 3841-3848. [CrossRef]

174. Rashad, M.; Shaalan, N.M.; Abd-Elnaiem, A.M. Degradation enhancement of methylene blue on ZnO nanocombs synthesized by thermal evaporation technique. Desalin. Water Treat. 2016, 57, 26267-26273. [CrossRef]

175. Siong, V.L.E.; Lee, K.M.; Juan, J.C.; Lai, C.W.; Tai, X.H.; Khe, C.S. Removal of methylene blue dye by solvothermally reduced graphene oxide: A metal-free adsorption and photodegradation method. RSC Adv. 2019, 9, 37686-37695. [CrossRef]

176. León, E.R.; Rodríguez, E.L.; Beas, C.R.; Plascencia-Villa, G.; Palomares, R.A.I. Study of Methylene Blue Degradation by Gold Nanoparticles Synthesized within Natural Zeolites. J. Nanomater. 2016, 2016, 9541683. [CrossRef]

177. Saraswati, T.E.; Andhika, I.F.; Patiha; Purnawan, C.; Wahyuningsih, S.; Anwar, M. Photocatalytic Degradation of Methylene Blue Using $\mathrm{TiO}_{2}$ /Carbon Nanoparticles Fabricated by Electrical Arc Discharge in Liquid Medium. Adv. Mater. Res. 2015, 1123, 285-288. [CrossRef]

178. Hou, L.; Yang, L.; Li, J.; Tan, J.; Yuan, C. Efficient sunlight-induced methylene blue removal over one-dimensional mesoporous monoclinic $\mathrm{BiVO}_{4}$ nanorods. J. Anal. Methods Chem. 2012, 2012, 345247. [CrossRef] [PubMed]

179. Soltani, T.; Entezari, M.H. Photolysis and photocatalysis of methylene blue by ferrite bismuth nanoparticles under sunlight irradiation. J. Mol. Catal. A Chem. 2013, 377, 197-203. [CrossRef]

180. Rajendran, S.; Khan, M.M.; Gracia, F.; Qin, J.; Gupta, V.K.; Arumainathan, S. Ce ${ }^{3+}{ }_{-}$ion-induced visible-light photocatalytic degradation and electrochemical activity of $\mathrm{ZnO} / \mathrm{CeO}_{2}$ nanocomposite. Sci. Rep. 2016, 6, 31641. [CrossRef] [PubMed]

181. Ullah, S.; Ahmad, A.; Ri, H.; Khan, A.U.; Khan, U.A.; Yuan, Q. Green synthesis of catalytic Zinc Oxide nano-flowers and their bacterial infection therapy. Appl. Organomet. Chem. 2020, 34, e5298. [CrossRef]

182. Sáenz-Trevizo, A.; Pizá-Ruiz, P.; Chávez-Flores, D.; Ogaz-Parada, J.; Amézaga-Madrid, P.; Vega-Ríos, A.; Miki-Yoshida, M. On the Discoloration of Methylene Blue by Visible Light. J. Fluoresc. 2019, 29, 15-25. [CrossRef]

183. Shahabuddin, S.; Sarih, N.M.; Mohamad, S.; Ching, J.J. SrTiO 3 nanocube-doped polyaniline nanocomposites with enhanced photocatalytic degradation of methylene blue under visible light. Polymers 2016, 8, 27. [CrossRef]

184. Saeed, K.; Khan, I.; Park, S.Y. TiO 2 /amidoxime-modified polyacrylonitrile nanofibers and its application for the photodegradation of methyl blue in aqueous medium. Desalin. Water Treat. 2015, 54, 3146-3151. [CrossRef]

185. Balu, S.; Uma, K.; Pan, G.T.; Yang, T.C.K.; Ramaraj, S.K. Degradation of methylene blue dye in the presence of visible light using $\mathrm{SiO}_{2} @ \alpha-\mathrm{Fe}_{2} \mathrm{O}_{3}$ nanocomposites deposited on SnS2 flowers. Materials 2018, 11, 1030. [CrossRef]

186. Yu, Z.; Chuang, S.S.C. Probing methylene blue photocatalytic degradation by adsorbed ethanol with in situ IR. J. Phys. Chem. C 2007, 111, 13813-13820. [CrossRef] 
187. Yang, C.; Wang, X.; Ji, Y.; Ma, T.; Zhang, F.; Wang, Y.; Ci, M.; Chen, D.; Jiang, A.; Wang, W. Photocatalytic degradation of methylene blue with ZnO@C nanocomposites: Kinetics, mechanism, and the inhibition effect on monoamine oxidase A and B. NanoImpact 2019, 15, 100174. [CrossRef]

188. Dagher, S.; Soliman, A.; Ziout, A.; Tit, N.; Hilal-Alnaqbi, A.; Khashan, S.; Alnaimat, F.; Qudeiri, J.A. Photocatalytic removal of methylene blue using titania- and silica-coated magnetic nanoparticles. Mater. Res. Express 2018, 5, 65518. [CrossRef]

189. Kuila, S.K.; Sarkar, R.; Kumbhakar, P.; Kumbhakar, P.; Tiwary, C.S.; Kundu, T.K. Photocatalytic dye degradation under sunlight irradiation using cerium ion adsorbed two-dimensional graphitic carbon nitride. J. Environ. Chem. Eng. 2020, 8, 103942. [CrossRef]

190. Hanif, M.; Lee, I.; Akter, J.; Islam, M.; Zahid, A.; Sapkota, K.; Hahn, J. Enhanced Photocatalytic and Antibacterial Performance of ZnO Nanoparticles Prepared by an Efficient Thermolysis Method. Catalysts 2019, 9, 608. [CrossRef]

191. Nuengmatcha, P.; Porrawatkul, P.; Chanthai, S.; Sricharoen, P.; Limchoowong, N. Enhanced photocatalytic degradation of methylene blue using Fe2O3/graphene/CuO nanocomposites under visible light. J. Environ. Chem. Eng. 2019, 7, 103438. [CrossRef]

192. Trandafilović, L.V.; Jovanović, D.J.; Zhang, X.; Ptasińska, S.; Dramićanin, M.D. Enhanced photocatalytic degradation of methylene blue and methyl orange by ZnO:Eu nanoparticles. Appl. Catal. B Environ. 2017, 203, 740-752. [CrossRef]

193. Zuo, R.; Du, G.; Zhang, W.; Liu, L.; Liu, Y.; Mei, L.; Li, Z. Photocatalytic degradation of methylene blue using $\mathrm{TiO}_{2}$ impregnated diatomite. Adv. Mater. Sci. Eng. 2014, 2014, 170148. [CrossRef]

194. Houas, A.; Lachheb, H.; Ksibi, M.; Elaloui, E.; Guillard, C.; Herrmann, J.M. Photocatalytic degradation pathway of methylene blue in water. Appl. Catal. B Environ. 2001, 31, 145-157. [CrossRef]

195. Singh, J.; Dhaliwal, A.S. Plasmon-induced photocatalytic degradation of methylene blue dye using biosynthesized silver nanoparticles as photocatalyst. Environ. Technol. 2020, 41, 1520-1534. [CrossRef]

196. Smazna, D.; Shree, S.; Polonskyi, O.; Lamaka, S.; Baum, M.; Zheludkevich, M.; Faupel, F.; Adelung, R.; Mishra, Y.K. Mutual interplay of $\mathrm{ZnO}$ micro- and nanowires and methylene blue during cyclic photocatalysis process. J. Environ. Chem. Eng. 2019, 7, 103016. [CrossRef]

197. da Silva, L.F.; Lopes, O.F.; de Mendonça, V.R.; Carvalho, K.T.G.; Longo, E.; Ribeiro, C.; Mastelaro, V.R. An Understanding of the Photocatalytic Properties and Pollutant Degradation Mechanism of $\mathrm{SrTiO}_{3}$ Nanoparticles. Photochem. Photobiol. 2016, 92, 371-378. [CrossRef] [PubMed]

198. Gu, W.; Teng, F. SPR-promoted visible-light photocatalytic activity of Bi/ZIF hybrids. J. Photochem. Photobiol. A Chem. 2020, $400,112679$. [CrossRef]

199. Rahmat, M.; Rehman, A.; Rahmat, S.; Bhatti, H.N.; Iqbal, M.; Khan, W.S.; Bajwa, S.Z.; Rahmat, R.; Nazir, A. Highly efficient removal of crystal violet dye from water by $\mathrm{MnO}_{2}$ based nanofibrous mesh/photocatalytic process. J. Mater. Res. Technol. 2019, 8 , 5149-5159. [CrossRef]

200. Ashrafi, H.; Akhond, M.; Absalan, G. Adsorption and Photocatalytic Degradation of Aqueous Methylene Blue using Nanoporous Carbon Nitride. J. Photochem. Photobiol. A Chem. 2020, 396, 112533. [CrossRef]

201. Prasert, A.; Sontikaew, S.; Sriprapai, D.; Chuangchote, S. Polypropylene/ZnO Nanocomposites: Mechanical Properties, Photocatalytic Dye Degradation, and Antibacterial Property. Materials 2020, 13, 914. [CrossRef]

202. Isai, K.A.; Shrivastava, V.S. Photocatalytic degradation of methylene blue using $\mathrm{ZnO}$ and $2 \% \mathrm{Fe}-\mathrm{ZnO}$ semiconductor nanomaterials synthesized by sol-gel method: A comparative study. SN Appl. Sci. 2019, 1, 1247. [CrossRef]

203. Janani, B.; Gayathri, G.; Syed, A.; Raju, L.L.; Marraiki, N.; Elgorban, A.M.; Thomas, A.M.; Khan, S.S. The Effect of Various Capping Agents on Surface Modifications of CdO NPs and the Investigation of Photocatalytic Performance, Antibacterial and Anti-biofilm Activities. J. Inorg. Organomet. Polym. Mater. 2020, 30, 1865-1876. [CrossRef]

204. Ali Baig, A.B.; Rathinam, V.; Palaninathan, J. Photodegradation activity of yttrium-doped $\mathrm{SnO}_{2}$ nanoparticles against methylene blue dye and antibacterial effects. Appl. Water Sci. 2020, 10, 76. [CrossRef]

205. Chen, Y.; Xiang, Z.; Wang, D.; Kang, J.; Qi, H. Effective photocatalytic degradation and physical adsorption of methylene blue using cellulose/GO/ $\mathrm{TiO}_{2}$ hydrogels. RSC Adv. 2020, 10, 23936-23943. [CrossRef]

206. Alkaykh, S.; Mbarek, A.; Ali-Shattle, E.E. Photocatalytic degradation of methylene blue dye in aqueous solution by $\mathrm{MnTiO}_{3}$ nanoparticles under sunlight irradiation. Heliyon 2020, 6, e03663. [CrossRef]

207. Enesca, A.; Isac, L. The Influence of Light Irradiation on the Photocatalytic Degradation of Organic Pollutants. Materials 2020, 13, 2494. [CrossRef]

208. Zhang, J.; Su, C.; Xie, X.; Liu, P.; Huq, M.E. Enhanced visible light photocatalytic degradation of dyes in aqueous solution activated by HKUST-1: Performance and mechanism. RSC Adv. 2020, 10, 37028-37034. [CrossRef]

209. Du, Z.; Cui, C.; Zhang, S.; Xiao, H.; Ren, E.; Guo, R.; Jiang, S. Visible-light-driven photocatalytic degradation of rhodamine B using $\mathrm{Bi}_{2} \mathrm{WO}_{6} / \mathrm{GO}$ deposited on polyethylene terephthalate fabric. J. Leather Sci. Eng. 2020, 2, 16. [CrossRef]

210. Acosta-Esparza, M.A.; Rivera, L.P.; Pérez-Centeno, A.; Zamudio-Ojeda, A.; González, D.R.; Chávez-Chávez, A.; Santana-Aranda, M.A.; Santos-Cruz, J.; Quiñones-Galván, J.G. UV and Visible light photodegradation of methylene blue with graphene decorated titanium dioxide. Mater. Res. Express 2020, 7, 035504. [CrossRef]

211. Zeleke, M.A.; Kuo, D.H. Synthesis and application of $\mathrm{V}_{2} \mathrm{O}_{5}-\mathrm{CeO}_{2}$ nanocomposite catalyst for enhanced degradation of methylene blue under visible light illumination. Chemosphere 2019, 235, 935-944. [CrossRef]

212. Salama, A.; Mohamed, A.; Aboamera, N.M.; Osman, T.A.; Khattab, A. Photocatalytic degradation of organic dyes using composite nanofibers under UV irradiation. Appl. Nanosci. 2018, 8, 155-161. [CrossRef] 
213. Elsayed, E.M.; Elnouby, M.S.; Gouda, S.M.H.; Elessawy, N.A.; Santos, D.M.F. Effect of the morphology of tungsten oxide embedded in sodium alginate/polyvinylpyrrolidone composite beads on the photocatalytic degradation of methylene blue dye solution. Materials 2020, 13, 1905. [CrossRef]

214. Anju Chanu, L.; Joychandra Singh, W.; Jugeshwar Singh, K.; Nomita Devi, K. Effect of operational parameters on the photocatalytic degradation of Methylene blue dye solution using manganese doped ZnO nanoparticles. Results Phys. 2019, 12, $1230-1237$. [CrossRef]

215. Pandey, A.; Kalal, S.; Ameta, C.; Ameta, R.; Kumar, S.; Punjabi, P.B. Synthesis, characterization and application of naïve and nano-sized titanium dioxide as a photocatalyst for degradation of methylene blue. J. Saudi Chem. Soc. 2015, 19, 528-536. [CrossRef]

216. Xu, C.; Rangaiah, G.P.; Zhao, X.S. Photocatalytic degradation of methylene blue by titanium dioxide: Experimental and modeling study. Ind. Eng. Chem. Res. 2014, 53, 14641-14649. [CrossRef]

217. Chowdhury, P.R.; Bhattacharyya, K.G. Ni/Ti layered double hydroxide: Synthesis, characterization and application as a photocatalyst for visible light degradation of aqueous methylene blue. Dalton Trans. 2015, 44, 6809-6824. [CrossRef] [PubMed]

218. Abdellah, M.H.; Nosier, S.A.; El-Shazly, A.H.; Mubarak, A.A. Photocatalytic decolorization of methylene blue using TiO $2 / \mathrm{UV}$ system enhanced by air sparging. Alex. Eng. J. 2018, 57, 3727-3735. [CrossRef]

219. Alkaim, A.F.; Aljeboree, A.M.; Alrazaq, N.A.; Baqir, S.J.; Hussein, F.H.; Lilo, A.J. Effect of pH on adsorption and photocatalytic degradation efficiency of different catalysts on removal of methylene blue. Asian J. Chem. 2014, 26, 8445-8448. [CrossRef]

220. Singh, R.K.; Behera, S.S.; Singh, K.R.; Mishra, S.; Panigrahi, B.; Sahoo, T.R.; Parhi, P.K.; Mandal, D. Biosynthesized gold nanoparticles as photocatalysts for selective degradation of cationic dye and their antimicrobial activity. J. Photochem. Photobiol. A Chem. 2020, 400, 112704. [CrossRef]

221. Azeez, F.; Al-Hetlani, E.; Arafa, M.; Abdelmonem, Y.; Nazeer, A.A.; Amin, M.O.; Madkour, M. The effect of surface charge on photocatalytic degradation of methylene blue dye using chargeable titania nanoparticles. Sci. Rep. 2018, 8, 7104. [CrossRef]

222. Saeed, K.; Zada, N.; Khan, I.; Sadiq, M. Synthesis, characterization and photodegradation application of Fe-Mn and F-MWCNTs supported Fe-Mn oxides nanoparticles. Desalin. Water Treat. 2018, 108, 362-368. [CrossRef]

223. Nguyen Thi Thu, T.; Nguyen Thi, N.; Tran Quang, V.; Nguyen Hong, K.; Nguyen Minh, T.; Le Thi Hoai, N. Synthesis, characterisation, and effect of $\mathrm{pH}$ on degradation of dyes of copper-doped $\mathrm{TiO}_{2}$. J. Exp. Nanosci. 2016, 11, 226-238. [CrossRef]

224. Hejazi, R.; Mahjoub, A.R.; Khavar, A.H.C.; Khazaee, Z. Fabrication of novel type visible-light-driven TiO $@ @ \mathrm{MIL}^{-100}$ (Fe) microspheres with high photocatalytic performance for removal of organic pollutants. J. Photochem. Photobiol. A Chem. 2020, 400, 112644. [CrossRef]

225. Hendekhale, N.R.; Mohammad-Khah, A. A novel synthesis of $\mathrm{Co}_{2} \mathrm{ZrO}_{5}$ and $\mathrm{m}-\mathrm{ZrO}_{2}$ nanoparticles by sono-precipitation and hydrothermal methods and their application in UV/Visible-photocatalytic studies. J. Environ. Chem. Eng. 2020, 8, 104065. [CrossRef]

226. Di Mauro, A.; Cantarella, M.; Nicotra, G.; Pellegrino, G.; Gulino, A.; Brundo, M.V.; Privitera, V.; Impellizzeri, G. Novel synthesis of ZnO/PMMA nanocomposites for photocatalytic applications. Sci. Rep. 2017, 7, 40895. [CrossRef]

227. Jia, Z.; La, L.B.T.; Zhang, W.C.; Liang, S.X.; Jiang, B.; Xie, S.K.; Habibi, D.; Zhang, L.C. Strong enhancement on dye photocatalytic degradation by ball-milled $\mathrm{TiO}_{2}$ : A study of cationic and anionic dyes. J. Mater. Sci. Technol. 2017, 33, 856-863. [CrossRef]

228. Mohammadzadeh, A.; Khoshghadam-Pireyousefan, M.; Shokrianfard-Ravasjan, B.; Azadbeh, M.; Rashedi, H.; Dibazar, M.; Mostafaei, A. Synergetic photocatalytic effect of high purity $\mathrm{ZnO}$ pod shaped nanostructures with $\mathrm{H}_{2} \mathrm{O}_{2}$ on methylene blue dye degradation. J. Alloys Compd. 2020, 845, 156333. [CrossRef]

229. Reza, K.M.; Kurny, A.; Gulshan, F. Parameters affecting the photocatalytic degradation of dyes using TiO 2 : A review. Appl. Water Sci. 2017, 7, 1569-1578. [CrossRef]

230. Zhang, M.; Wang, L.; Zeng, T.; Shang, Q.; Zhou, H.; Pan, Z.; Cheng, Q. Two pure MOF-photocatalysts readily prepared for the degradation of methylene blue dye under visible light. Dalton Trans. 2018, 47, 4251-4258. [CrossRef]

231. Tadkar, P.S.; Borkar, P.K.; Gholap, S.N.; Gole, V.L. Treatment of Methylene Blue Dye Using Immersed Lamp Photocatalytic Reactor: 5 L Scale Study. J. Inst. Eng. Ser. E 2019, 100, 199-204. [CrossRef]

232. Singh, J.; Chang, Y.Y.; Koduru, J.R.; Yang, J.K. Potential degradation of methylene blue (MB) by nano-metallic particles: A kinetic study and possible mechanism of MB degradation. Environ. Eng. Res. 2018, 23, 1-9. [CrossRef]

233. Wang, Q.; Wang, X.; Liu, S.; Li, R. Efficient decolorization of Methylene Blue catalyzed by MgFe-layered double hydroxides in the presence of hydrogen peroxide. Water Sci. Technol. 2020, 81, 781-789. [CrossRef]

234. Pudukudy, M.; Yaakob, Z.; Rajendran, R.; Kandaramath, T. Photodegradation of methylene blue over novel 3D ZnO microflowers with hexagonal pyramid-like petals. React. Kinet. Mech. Catal. 2014, 112, 527-542. [CrossRef]

235. Wang, X.; Liu, P.; Fu, M.; Ma, J.; Ning, P. Novel sequential process for enhanced dye synergistic degradation based on nano zero-valent iron and potassium permanganate. Chemosphere 2016, 155, 39-47. [CrossRef]

236. Sharma, C.P.; Karim, A.V.; Shriwastav, A. Decolorization of methylene blue using Fe(III)-citrate complex in a solar photo-Fenton process: Impact of solar variability on process optimization. Water Sci. Technol. 2019, 80, 2047-2057. [CrossRef]

237. Ngullie, R.C.; Alaswad, S.O.; Bhuvaneswari, K.; Shanmugam, P.; Pazhanivel, T.; Arunachalam, P. Synthesis and Characterization of Efficient $\mathrm{ZnO} / \mathrm{g}-\mathrm{C}_{3} \mathrm{~N}_{4}$ Nanocomposites Photocatalyst for Photocatalytic Degradation of Methylene Blue. Coatings 2020, 10, 500. [CrossRef]

238. Guo, Z.; Wang, G.; Fu, H.; Wang, P.; Liao, J.; Wang, A. Photocatalytic degradation of methylene blue by a cocatalytic PDA/TiO 2 electrode produced by photoelectric polymerization. RSC Adv. 2020, 10, 26133-26141. [CrossRef] 
239. Zheng, Y.; Cao, L.; Xing, G.; Bai, Z.; Huang, J.; Zhang, Z. Microscale flower-like magnesium oxide for highly efficient photocatalytic degradation of organic dyes in aqueous solution. RSC Adv. 2019, 9, 7338-7348. [CrossRef]

240. Salgado, B.C.B.; Valentini, A. Evaluation of the photocatalytic activity of $\mathrm{SiO}_{2} @ \mathrm{TiO}_{2}$ hybrid spheres in the degradation of methylene blue and hydroxylation of benzene: Kinetic and mechanistic study. Braz. J. Chem. Eng. 2019, 36, 1501-1518. [CrossRef]

241. Lee, S.; Park, J.-W. Hematite/Graphitic Carbon Nitride Nanofilm for Fenton and Photocatalytic Oxidation of Methylene Blue. Sustainability 2020, 12, 2866. [CrossRef]

242. Shelar, S.G.; Mahajan, V.K.; Patil, S.P.; Sonawane, G.H. Effect of doping parameters on photocatalytic degradation of methylene blue using Ag doped ZnO nanocatalyst. SN Appl. Sci. 2020, 2, 820. [CrossRef]

243. Saeed, M.; Muneer, M.; Khosa, M.K.K.; Akram, N.; Khalid, S.; Adeel, M.; Nisar, A.; Sherazi, S. Azadirachta indica leaves extract assisted green synthesis of $\mathrm{Ag}-\mathrm{TiO}_{2}$ for degradation of Methylene blue and Rhodamine B dyes in aqueous medium. Green Process. Synth. 2019, 8, 659-666. [CrossRef]

244. Yang, C.; Dong, W.; Cui, G.; Zhao, Y.; Shi, X.; Xia, X.; Tang, B.; Wang, W. Highly-efficient photocatalytic degradation of methylene blue by PoPD-modified $\mathrm{TiO}_{2}$ nanocomposites due to photosensitization-synergetic effect of $\mathrm{TiO}_{2}$ with PoPD. Sci. Rep. 2017, 7, 3973. [CrossRef] [PubMed]

245. Pan, X.; Cheng, S.; Su, T.; Zuo, G.; Zhao, W.; Qi, X.; Wei, W.; Dong, W. Fenton-like catalyst $\mathrm{Fe}_{3} \mathrm{O}_{4} @ \mathrm{polydopamine-MnO}_{2}$ for enhancing removal of methylene blue in wastewater. Colloids Surf. B Biointerfaces 2019, 181, 226-233. [CrossRef] [PubMed]

246. Xu, P.; Li, K.; Yu, H.; Cohen Stuart, M.A.; Wang, J.; Zhou, S. One-Pot Syntheses of Porous Hollow Silica Nanoreactors Encapsulating Rare Earth Oxide Nanoparticles for Methylene Blue Degradation. Ind. Eng. Chem. Res. 2019, 58, 3726-3734. [CrossRef]

247. Rodríguez-Chueca, J.; Alonso, E.; Singh, D. Photocatalytic Mechanisms for Peroxymonosulfate Activation through the Removal of Methylene Blue: A Case Study. Int. J. Environ. Res. Public Health 2019, 16, 198. [CrossRef]

248. Saleh, R.; Taufik, A. Photo-Fenton degradation of methylene blue in the presence of $\mathrm{Au}-\mathrm{Fe}_{3} \mathrm{O}_{4} /$ graphene composites under UV and visible light at near neutral pH: Effect of coexisting inorganic anion. Environ. Nanotechnol. Monit. Manag. 2019, $11,100221$. [CrossRef]

249. Cheng, X.; Chong, R.; Cao, Y.; Li, D.; Chang, Z.; Zhang, L. Influence of inorganic anions on photocatalytic degeneration of methylene blue on $\mathrm{Ag}_{3} \mathrm{PO}_{4}$. J. Nanosci. Nanotechnol. 2016, 16, 12489-12497. [CrossRef]

250. Gupta, N.K.; Ghaffari, Y.; Kim, S.; Bae, J.; Kim, K.S.; Saifuddin, M. Photocatalytic Degradation of Organic Pollutants over MFe $\mathrm{O}_{4}$ $(\mathrm{M}=\mathrm{Co}, \mathrm{Ni}, \mathrm{Cu}, \mathrm{Zn})$ Nanoparticles at Neutral pH. Sci. Rep. 2020, 10, 4942. [CrossRef] [PubMed]

251. Liu, Y.; Yu, H.; Lv, Z.; Zhan, S.; Yang, J.; Peng, X.; Ren, Y.; Wu, X. Simulated-sunlight-activated photocatalysis of Methylene Blue using cerium-doped $\mathrm{SiO}_{2} / \mathrm{TiO}_{2}$ nanostructured fibers. J. Environ. Sci. 2012, 24, 1867-1875. [CrossRef]

252. Sahoo, C.; Gupta, A.K.; Sasidharan Pillai, I.M. Photocatalytic degradation of methylene blue dye from aqueous solution using silver ion-doped $\mathrm{TiO}_{2}$ and its application to the degradation of real textile wastewater. J. Environ. Sci. Health-Part A Toxic/Hazard. Subst. Environ. Eng. 2012, 47, 1428-1438. [CrossRef] [PubMed]

253. Sun, L.; Shao, Q.; Zhang, Y.; Jiang, H.; Ge, S.; Lou, S.; Lin, J.; Zhang, J.; Wu, S.; Dong, M.; et al. N self-doped ZnO derived from microwave hydrothermal synthesized zeolitic imidazolate framework-8 toward enhanced photocatalytic degradation of methylene blue. J. Colloid Interface Sci. 2020, 565, 142-155. [CrossRef]

254. Tang, S.; Wang, Z.; Yuan, D.; Zhang, Y.; Qi, J.; Rao, Y.; Lu, G.; Li, B.; Wang, K.; Yin, K. Enhanced photocatalytic performance of $\mathrm{BiVO}_{4}$ for degradation of methylene blue under LED visible light irradiation assisted by peroxymonosulfate. Int. J. Electrochem. Sci. 2020, 15, 2470-2480. [CrossRef]

255. Das, G.S.; Shim, J.P.; Bhatnagar, A.; Tripathi, K.M.; Kim, T.Y. Biomass-derived Carbon Quantum Dots for Visible-Light-Induced Photocatalysis and Label-Free Detection of Fe(III) and Ascorbic acid. Sci. Rep. 2019, 9, 15084. [CrossRef]

256. Atta, A.M.; Moustafa, Y.M.; Al-Lohedan, H.A.; Ezzat, A.O.; Hashem, A.I. Methylene Blue Catalytic Degradation Using Silver and Magnetite Nanoparticles Functionalized with a Poly(ionic liquid) Based on Quaternized Dialkylethanolamine with 2-Acrylamido2-methylpropane Sulfonate- co-Vinylpyrrolidone. ACS Omega 2020, 5, 2829-2842. [CrossRef] [PubMed]

257. Zhou, L.; Shao, Y.; Liu, J.; Ye, Z.; Zhang, H.; Ma, J.; Jia, Y.; Gao, W.; Li, Y. Preparation and characterization of magnetic porous carbon microspheres for removal of methylene blue by a heterogeneous fenton reaction. ACS Appl. Mater. Interfaces 2014, 6 , 7275-7285. [CrossRef] [PubMed]

258. Antoniadou, M.; Arfanis, M.K.; Ibrahim, I.; Falaras, P. Bifunctional g- $\mathrm{C}_{3} \mathrm{~N}_{4} / \mathrm{WO}_{3}$ thin films for photocatalyticwater purification. Water 2019, 11, 2439. [CrossRef]

259. Rauf, M.A.; Meetani, M.A.; Khaleel, A.; Ahmed, A. Photocatalytic degradation of Methylene Blue using a mixed catalyst and product analysis by LC/MS. Chem. Eng. J. 2010, 157, 373-378. [CrossRef]

260. Sithole, R.K.; Machogo, L.F.E.; Moloto, M.J.; Gqoba, S.S.; Mubiayi, K.P.; Van Wyk, J.; Moloto, N. One-step synthesis of $\mathrm{Cu}_{3}$ N, Cu $2 \mathrm{~S}$ and $\mathrm{Cu}_{9} \mathrm{~S}_{5}$ and photocatalytic degradation of methyl orange and methylene blue. J. Photochem. Photobiol. A Chem. 2020, $397,112577$. [CrossRef]

261. Wolski, L.; Ziolek, M. Insight into pathways of methylene blue degradation with $\mathrm{H}_{2} \mathrm{O}_{2}$ over mono and bimetallic $\mathrm{Nb}$, $\mathrm{Zn}$ oxides. Appl. Catal. B Environ. 2018, 224, 634-647. [CrossRef]

262. Wang, Q.; Tian, S.; Ning, P. Degradation mechanism of methylene blue in a heterogeneous fenton-like reaction catalyzed by ferrocene. Ind. Eng. Chem. Res. 2014, 53, 643-649. [CrossRef]

263. Chithambararaj, A.; Sanjini, N.S.; Bose, A.C.; Velmathi, S. Flower-like hierarchical h-MoO${ }_{3}$ : New findings of efficient visible light driven nano photocatalyst for methylene blue degradation. Catal. Sci. Technol. 2013, 3, 1405-1414. [CrossRef] 
264. Lee, J.E.; Khoa, N.T.; Kim, S.W.; Kim, E.J.; Hahn, S.H. Fabrication of Au/GO/ZnO composite nanostructures with excellent photocatalytic performance. Mater. Chem. Phys. 2015, 164, 29-35. [CrossRef]

265. Mohamadi, S.; Ghorbanali, M. Adsorption and UV-assisted photodegradation of methylene blue by $\mathrm{CeO}_{2}$-decorated graphene sponge. Sep. Sci. Technol. 2020. [CrossRef]

266. Azzam, E.M.S.; Fathy, N.A.; El-Khouly, S.M.; Sami, R.M. Enhancement the photocatalytic degradation of methylene blue dye using fabricated $\mathrm{CNTs} / \mathrm{TiO}_{2} / \mathrm{AgNPs} /$ Surfactant nanocomposites. J. Water Process Eng. 2019, 28, 311-321. [CrossRef]

267. Hoan, N.T.V.; Minh, N.N.; Nhi, T.T.K.; Van Thang, N.; Tuan, V.A.; Nguyen, V.T.; Thanh, N.M.; Van Hung, N.; Khieu, D.Q $\mathrm{TiO}_{2}$ /Diazonium/graphene oxide composites: Synthesis and visible-light-driven photocatalytic degradation of methylene blue. J. Nanomater. 2020, 2020, 4350125. [CrossRef]

268. Atique Ullah, A.K.M.; Fazle Kibria, A.K.M.; Akter, M.; Khan, M.N.I.; Tareq, A.R.M.; Firoz, S.H. Oxidative Degradation of Methylene Blue Using $\mathrm{Mn}_{3} \mathrm{O}_{4}$ Nanoparticles. Water Conserv. Sci. Eng. 2017, 1, 249-256. [CrossRef]

269. Zhang, Z.; Li, X.; Chen, H.; Shao, G.; Zhang, R.; Lu, H. Synthesis and properties of Ag/ZnO/g- $\mathrm{C}_{3} \mathrm{~N}_{4}$ ternary micro/nano composites by microwave-assisted method. Mater. Res. Express 2018, 5, 015021. [CrossRef]

270. Lee, K.M.; Lai, C.W.; Ngai, K.S.; Juan, J.C. Recent developments of zinc oxide based photocatalyst in water treatment technology: A review. Water Res. 2016, 88, 428-448. [CrossRef]

271. Kumar, N.; Mittal, H.; Reddy, L.; Nair, P.; Ngila, J.C.; Parashar, V. Morphogenesis of ZnO nanostructures: Role of acetate (COOH-) and nitrate $\left(\mathrm{NO}_{3}-\right)$ ligand donors from zinc salt precursors in synthesis and morphology dependent photocatalytic properties. RSC Adv. 2015, 5, 38801-38809. [CrossRef]

272. He, D.; Lin, F. Preparation and photocatalytic activity of anatase $\mathrm{TiO}_{2}$ nanocrystallites with high thermal stability. Mater. Lett. 2007, 61, 3385-3387. [CrossRef]

273. Khan, I.; Khan, A.A.Z.; Sufyan, A.; Khan, M.Y.; Inayath Basha, S.; Khan, A.A.Z. Ultrasonically controlled growth of monodispersed octahedral $\mathrm{BiVO}_{4}$ microcrystals for improved photoelectrochemical water oxidation. Ultrason. Sonochem. 2020, 68, 105233. [CrossRef]

274. Khan, I. Strategies for Improved Electrochemical $\mathrm{CO}_{2}$ Reduction to Value-added Products by Highly Anticipated Copper-based Nanoarchitectures. Chem. Rec. 2021, 22, e202100219. [CrossRef] [PubMed]

275. Khan, I.; Jalilov, A.; Fujii, K.; Qurashi, A. Quasi-1D Aligned Nanostructures for Solar-Driven Water Splitting Applications: Challenges, Promises, and Perspectives. Sol. RRL 2021, 5, 2000741. [CrossRef]

276. Ehsan, M.F.; Fazal, A.; Hamid, S.; Arfan, M.; Khan, I.; Usman, M.; Shafiee, A.; Ashiq, M.N. CoFe $\mathrm{O}_{4}$ decorated g-C ${ }_{3} \mathrm{~N}_{4}$ nanosheets: New insights into superoxide anion mediated photomineralization of methylene blue. J. Environ. Chem. Eng. 2020, 8, 104556. [CrossRef]

277. Ismael, $\mathrm{M}$.; $\mathrm{Wu}, \mathrm{Y}$. A mini-review on the synthesis and structural modification of $\mathrm{g}-\mathrm{C}_{3} \mathrm{~N}_{4}$-based materials, and their applications in solar energy conversion and environmental remediation. Sustain. Energy Fuels 2019, 3, 2907-2925. [CrossRef]

278. Shang, M.; Wang, W.; Zhou, L.; Sun, S.; Yin, W. Nanosized $\mathrm{BiVO}_{4}$ with high visible-light-induced photocatalytic activity: Ultrasonic-assisted synthesis and protective effect of surfactant. J. Hazard. Mater. 2009, 172, 338-344. [CrossRef] [PubMed]

279. Poorsajadi, F.; Sayadi, M.H.; Hajiani, M.; Rezaei, M.R. Synthesis of $\mathrm{CuO} / \mathrm{Bi}_{2} \mathrm{O}_{3}$ nanocomposite for efficient and recycling photodegradation of methylene blue dye. Int. J. Environ. Anal. Chem. 2020. [CrossRef]

280. Albiss, B.; Abu-Dalo, M. Photocatalytic Degradation of Methylene Blue Using Zinc Oxide Nanorods Grown on Activated Carbon Fibers. Sustainability 2021, 13, 4729. [CrossRef]

281. Honarmand, M.; Golmohammadi, M.; Naeimi, A. Green synthesis of $\mathrm{SnO}_{2}$-bentonite nanocomposites for the efficient photodegradation of methylene blue and eriochrome black-T. Mater. Chem. Phys. 2020, 241, 122416. [CrossRef]

282. Faisal, M.; Harraz, F.A.; Jalalah, M.; Alsaiari, M.; Al-Sayari, S.A.; Al-Assiri, M.S. Polythiophene doped ZnO nanostructures synthesized by modified sol-gel and oxidative polymerization for efficient photodegradation of methylene blue and gemifloxacin antibiotic. Mater. Today Commun. 2020, 24, 101048. [CrossRef]

283. Wang, W.; Lin, F.; Yan, B.; Cheng, Z.; Chen, G.; Kuang, M.; Yang, C.; Hou, L. The role of seashell wastes in TiO $2 /$ Seashell composites: Photocatalytic degradation of methylene blue dye under sunlight. Environ. Res. 2020, 188, 109831. [CrossRef]

284. Sanad, M.M.S.; Farahat, M.M.; El-Hout, S.I.; El-Sheikh, S.M. Preparation and characterization of magnetic photocatalyst from the banded iron formation for effective photodegradation of methylene blue under UV and visible illumination. J. Environ. Chem. Eng. 2021, 9, 105127. [CrossRef]

285. Wei, X.; Wang, X.; Pu, Y.; Liu, A.; Chen, C.; Zou, W.; Zheng, Y.; Huang, J.; Zhang, Y.; Yang, Y.; et al. Facile ball-milling synthesis of $\mathrm{CeO}_{2} / \mathrm{g}-\mathrm{C}_{3} \mathrm{~N}_{4} \mathrm{Z}$-scheme heterojunction for synergistic adsorption and photodegradation of methylene blue: Characteristics, kinetics, models, and mechanisms. Chem. Eng. J. 2021, 420, 127719. [CrossRef]

286. Vavilapalli, D.S.; Peri, R.G.; Sharma, R.K.; Goutam, U.K.; Muthuraaman, B.; Ramachandra Rao, M.S.; Singh, S. g-C ${ }_{3} \mathrm{~N}_{4} / \mathrm{Ca}_{2} \mathrm{Fe}_{2} \mathrm{O}_{5}$ heterostructures for enhanced photocatalytic degradation of organic effluents under sunlight. Sci. Rep. 2021, 11, 19639. [CrossRef] [PubMed]

287. Cheng, J.; Wang, X.; Zhang, Z.; Shen, Y.; Chen, K.; Guo, Y.; Zhou, X.; Bai, R. Synthesis of flower-like Bi2O4/ZnO heterojunction and mechanism of enhanced photodegradation for organic contaminants under visible light. Res. Chem. Intermed. 2018, 44, 6569-6590. [CrossRef]

288. Drmosh, Q.A.; Hezam, A.; Hendi, A.H.Y.; Qamar, M.; Yamani, Z.H.; Byrappa, K. Ternary $\mathrm{Bi}_{2} \mathrm{~S}_{3} / \mathrm{MoS}_{2} / \mathrm{TiO}_{2}$ with double Z-scheme configuration as high performance photocatalyst. Appl. Surf. Sci. 2020, 499, 143938. [CrossRef] 
289. Selvam, S.; Sarkar, I. Bile salt induced solubilization of methylene blue: Study on methylene blue fluorescence properties and molecular mechanics calculation. J. Pharm. Anal. 2017, 7, 71-75. [CrossRef] [PubMed]

290. Pahang, F.; Parvin, P.; Ghafoori-Fard, H.; Bavali, A.; Moafi, A.A.; Tio, K.; Zno, K.; Al, K. Fluorescence properties of methylene blue molecules coupled with metal oxide nanoparticles. OSA Contin. 2020, 3, 688-697. [CrossRef]

291. Geçgel, Ü.; Özcan, G.; Gürpnar, G.Ç. Removal of methylene blue from aqueous solution by activated carbon prepared from pea shells (Pisum sativum). J. Chem. 2013, 2013, 614083. [CrossRef] 